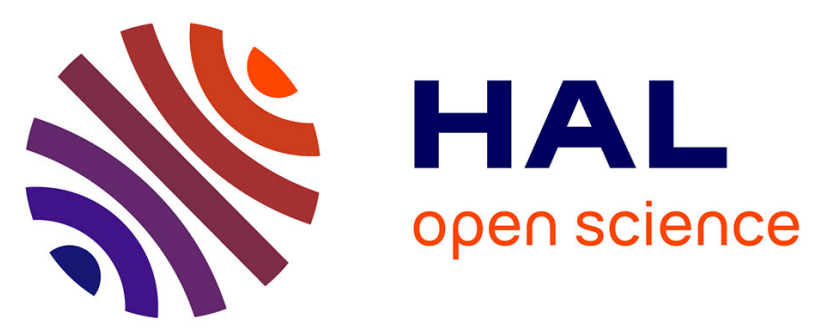

\title{
Metabolic, cellular and defense responses to single and co-exposure to carbamazepine and methylmercury in Dreissena polymorpha
}

Clément Baratange, Séverine Paris-Palacios, Isabelle Bonnard, Laurence Delahaut, Grandjean Dominique, Laurence Wortham, Stéphanie Sayen, Andrea Gallorini, Jean Michel, D Renault, et al.

\section{To cite this version:}

Clément Baratange, Séverine Paris-Palacios, Isabelle Bonnard, Laurence Delahaut, Grandjean Dominique, et al.. Metabolic, cellular and defense responses to single and co-exposure to carbamazepine and methylmercury in Dreissena polymorpha. Environmental Pollution, 2022, 300, pp.118933. 10.1016/j.envpol.2022.118933 . hal-03575444

\author{
HAL Id: hal-03575444 \\ https://hal.science/hal-03575444
}

Submitted on 15 Feb 2022

HAL is a multi-disciplinary open access archive for the deposit and dissemination of scientific research documents, whether they are published or not. The documents may come from teaching and research institutions in France or abroad, or from public or private research centers.
L'archive ouverte pluridisciplinaire HAL, est destinée au dépôt et à la diffusion de documents scientifiques de niveau recherche, publiés ou non, émanant des établissements d'enseignement et de recherche français ou étrangers, des laboratoires publics ou privés. 
Baratange Clément ${ }^{1}$, Paris-Palacios Séverine ${ }^{1}$, Bonnard Isabelle ${ }^{1}$, Delahaut Laurence ${ }^{1}$, Grandjean Dominique $^{2}$, Wortham Laurence ${ }^{3}$, Sayen Stéphanie ${ }^{4}$, Gallorini Andrea ${ }^{5}$, Michel Jean ${ }^{3}$, Renault David ${ }^{6,7}$, Breider Florian $^{2}$, Loizeau Jean-Luc ${ }^{5}$, Cosio Claudia ${ }^{1}$

(1)

1 Université de Reims Champagne-Ardenne, UMR-I 02 INERIS-URCA-ULH SEBIO, Unité Stress Environnementaux et BIOsurveillance des milieux aquatiques (SEBIO), BP 1039 F-51687 Reims Cedex, France.

${ }^{2}$ ENAC, IIE, Central Environmental Laboratory, Ecole polytechnique Fédérale de Lausanne (EPFL), Station 2, 1015 Lausanne, Switzerland.

${ }^{3}$ Inserm UMR-S-1250 P3Cell, Université de Reims Champagne-Ardenne, 51685 Reims Cedex 2.

${ }^{4}$ Université de Reims Champagne-Ardenne, Institut de Chimie Moléculaire de Reims (ICMR), UMR CNRS 7312, BP 1039, F-51687 Reims Cedex 2, France.

${ }^{5}$ Department F.-A. Forel for Environmental and Aquatic Sciences, and Institute for Environmental Sciences, University of Geneva, Boulevard Carl-Vogt 66, 1211 Geneva 4, Switzerland.

${ }^{6}$ University of Rennes, CNRS, ECOBIO [(Ecosystèmes, biodiversité, évolution)] - UMR 6553, Rennes, France.

${ }^{7}$ Institut Universitaire de France, 1 rue Descartes, 75231 Paris Cedex 05, France. 


\section{Abstract}

Carbamazepine (CBZ) and $\mathrm{Hg}$ are widespread and persistent micropollutants in aquatic environments. Both pollutants are known to trigger similar toxicity mechanisms, e.g. reactive oxygen species (ROS) production. Here, their effects were assessed in the zebra mussel Dreissena polymorpha, frequently used as a freshwater model in ecotoxicology and biomonitoring. Single and co-exposures to CBZ (3.9 $\left.\mathrm{\mu g} \cdot \mathrm{L}^{-1}\right)$ and $\mathrm{MeHg}$ (280 $\mathrm{ng} \cdot \mathrm{L}^{-1}$ ) were performed for 1 and 7 days. Metabolomics analyses evidenced that the co-exposure was the most disturbing after 7 days, reducing the amount of 25 metabolites involved in protein synthesis, energy metabolism, antioxidant response and osmoregulation, and significantly altering cells and organelles' structure supporting a reduction of functions of gills and digestive glands. CBZ alone after 7 days decreased the amount of $\alpha$-aminobutyric acid and had a moderate effect on the structure of mitochondria in digestive glands. MeHg alone had no effect on mussels' metabolome, but caused a significant alteration of cells and organelles' structure in gills and digestive glands. Single exposures and the co-exposure increased antioxidant responses vs control in gills and digestive glands, without resulting in lipid peroxidation, suggesting an increased ROS production caused by both pollutants. Data globally supported that a higher number of hyperactive cells compensated cellular alterations in the digestive gland of mussels exposed to $\mathrm{CBZ}$ or $\mathrm{MeHg}$ alone, while $\mathrm{CBZ}+\mathrm{MeHg}$ co-exposure overwhelmed this compensation after 7 days. Those effects were unpredictable based on cellular responses to CBZ and MeHg alone, highlighting the need to consider molecular toxicity pathways for a better anticipation of effects of pollutants in biota in complex environmental conditions.

Keywords: bioaccumulation, bivalve, cellular compensation, oxidative stress, toxicity pathways 


\section{Introduction}

Biomonitoring of freshwater ecosystems is useful to anticipate harmful effects of pollutants in aquatic biota. A current aim in stress biology is to combine endpoints at different levels of biological organization, molecular to individual, to gain a better vision of molecular toxicity pathways in the frame of the adverse outcome pathway theory (Brinke, 2017). This strategy also allows identifying early-warning responses, useful to anticipate undesired impacts on biota and mitigate pollutant effects. In the future, these tools could help avoid long and costly processes of remediation and as such will benefit a wide community. In this context, representative biota that is found widely in ecosystems are of special interest. The zebra mussel Dreissena polymorpha (Pallas, 1771) was identified as an interesting non-model species for freshwaters due to its abundance, its wide distribution, its sessile lifestyle and its filtering activity, which favors bioaccumulation of contaminants (Binelli et al., 2015; Louis et al., 2019; Prud'homme et al., 2020; Hani et al., 2021). Nonetheless, the physiology of $D$. polymorpha remains poorly known yet, limiting its efficient use in biomonitoring and ecotoxicology. A research priority is to gain a better understanding of the molecular toxicity pathways of pollutants in this promising model to improve the analysis of its responses in complex exposure scenarios and in situ.

The antiepileptic drug carbamazepine (CBZ) is a personal and pharmaceutical care product (PPCP). CBZ is widely found in aquatic ecosystems due to its high consumption and poor elimination by wastewater treatment plants (Celiz et al., 2009; Clara et al., 2004). CBZ was measured from <1 $\mathrm{ng} \cdot \mathrm{L}^{-1}$ to $10 \mu \mathrm{g} \cdot \mathrm{L}^{-1}$ in freshwaters (Sacher et al., 2001; Miao et al., 2005; Metcalfe et al., 2009; Calisto et al., 2011), and concentrations are expected to increase due to its persistence and high human consumption (Oldenkamp et al., 2019). At the European level, no legislation for CBZ in the aquatic environment is established yet, but an environmental quality standard (EQS) of $0.5 \mathrm{\mu g} \cdot \mathrm{L}^{-1}$ was recommended (Kase, 2010; ETOX, 2011; Moermond, 2014). In bivalves, CBZ triggers oxidative stress, defense responses, but also an alteration of the energy metabolism, genotoxicity and reprotoxicity (Martin-Diaz et al., 2009; Chen et al., 2014; Aguirre-Martínez et al., 2015; Almeida et al., 2015; Brandts et al., 2018; Magniez et al., 2018; Franzellitti et al., 2019). However, the precise molecular toxicity targets of CBZ remain unknown.

$\mathrm{Hg}$ is a persistent and widespread pollutant in aquatic ecosystems. This metal is considered as a priority pollutant in Europe (Directive 2008/105/EC) and by the Minamata international convention (Reg. EC 1881/2006). In Europe, the current EQS for $\mathrm{Hg}$ is $70 \mathrm{ng} \cdot \mathrm{L}^{-1}$. In aquatic ecosystems, methylmercury (MeHg) is biomagnified in food chains (Kershaw and Hall, 2019) and shows a lower depuration than inorganic mercury (IHg) in biota (Beauvais-Flück et al., 2017; Metian et al., 2020). In 
bivalves, IHg causes oxidative stress, defense responses, alteration of the energy metabolism, disturbances of protein translation and genotoxicity (Franzellitti and Fabbri, 2006; Liu et al., 2011a, 2011b; Navarro et al., 2011, 2012; Pytharopoulou et al., 2013; Jaumot et al., 2015; Velez et al., 2016; Coppola et al., 2017). Previous studies suggest that MeHg has different molecular toxicity pathways than $\mathrm{IHg}$ in biota, highlighting the need of assessing its impact in more detail for a better anticipation of risks it poses to ecosystems (Beauvais-Flück et al., 2017; Yang et al., 2020). Nonetheless, few studies focused on MeHg toxicity in bivalves (Gagnaire et al., 2004; Franzellitti and Fabbri, 2006; Parisi et al., 2021).

Scarce studies assessed toxic effects of co-exposure to ubiquitous pollutants, such as metals and organic pollutants (e.g. Almeida et al., 2018). CBZ and MeHg were selected here, because they are likely to be co-present in aquatic ecosystems (Andreu et al., 2016). Because CBZ and MeHg trigger similar cellular toxicity pathways, we hypothesized that their co-exposure would cause higher effects than single exposures. Here, metabolomic was analyzed in whole soft tissues to assess the phenotype at the individual level in D. polymorpha. In gills and digestive glands, histological and cytological analyses were performed, and lipid peroxidation, antioxidant and defense responses measured. The digestive gland is the organ where pollutants accumulate in higher concentrations, while gills are the most exposed organs to the environment. These two tissues are therefore highly relevant for the analysis of early cellular and molecular effects (Cardoso et al., 2013; Faggio et al., 2018). As such, this study aimed at answering the following questions: (i) which molecular toxicity pathways were induced by CBZ and MeHg? (ii) Does the co-exposure to CBZ and MeHg causes more effects than single exposures? (iii) Is there a link between observed effects and the bioaccumulation?

\section{Materials and methods}

\section{Exposures}

Individuals of Dreissena polymorpha were collected in the Der Lake (France; $48^{\circ} 36^{\prime} 22.02^{\prime \prime} \mathrm{N}$, $\left.4^{\circ} 46^{\prime} 34.0^{\prime \prime} \mathrm{E}\right)$ in October 2019 , transported to the laboratory, cleaned, selected by size (22-28 mm) and kept in water continuously aerated $\left(82 \% \mathrm{O}_{2}\right)$ at the field temperature $\left(14^{\circ} \mathrm{C}\right)$. Individuals were depurated for 7 days in $6 \mathrm{~L}$ of spring water (Cristaline Aurèle, table A1). For acclimation and to allow byssal fixation, 40 individuals per aquarium were transferred to 8 aquaria containing $3 \mathrm{~L}$ of spring water during 7 supplemental days. Animals were fed twice a week with a mixture of $50 \%$ Chlorella vulgaris and $50 \%$ Scenedesmus spp. using 2 million algae cells $\cdot$ day $^{-1} \cdot$ individual $^{-1}$ and water was renewed $24 \mathrm{~h}$ after feeding. Histological analysis of gonads showed a post-spawning pattern (Figure A1). Four exposures were conducted in 2 aquaria each: (1) control, (2) CBZ $\left(3.9 \pm 0.6 \mu \mathrm{g} \cdot \mathrm{L}^{-1}\right),(3) \mathrm{MeHg}$ 
113 German EQS for CBZ (ETOX, 2011) and 4x European EQS for Hg (Directive 2008/105/EC).

114 Temperature and feeding were identical to those during acclimation, but water was renewed daily. At D1, $2.50 \pm 1.02 \%$ of mussels died in the four aquaria, while $1.25 \pm 1.25 \%$ died at D7 in the four other aquaria. No significant differences were observed between exposures, thus mortality appeared negligible and unrelated to exposures.

For each exposure condition, mussels were sampled in one aquarium after 1 day (D1) and in the other aquarium after 7 days (D7). To mimic an active biomonitoring strategy (Louis et al., 2020), Individuals were elected as a replicate unit (Vaux et al., 2012) because of a high biological variability in this species (Pain Devin et al., 2014). This method ensured each individual had identical exposure conditions, hence limiting the impact of physiological and environmental conditions on toxicological effects and responses due to the pollutant (e.g. Louis et al., 2019). For bioaccumulation, whole soft tissues of nine animals were deshelled, rinsed with spring water and frozen at $-80^{\circ} \mathrm{C}$. For metabolomics, eight intact mussels were snap-frozen in liquid nitrogen and stored at $-20^{\circ} \mathrm{C}$. Histoand cytological analyses were performed on three to nine animals sampled at D7. For gene expression and biochemical analyses, digestive glands and gills of eight mussels were dissected, snapfrozen in liquid nitrogen and stored at $-80^{\circ} \mathrm{C}$. Water aliquots $(10 \mathrm{~mL})$ were filtered $(0.45 \mu \mathrm{m})$ immediately after the daily water renewal. First day samples were analyzed for the 1-day-long exposures, and other samples taken daily were pooled to analyze the average concentration of 7day-long exposures. Water samples were frozen at $-20^{\circ} \mathrm{C}$ for $\mathrm{CBZ}$ and acidified to $0.5 \% \mathrm{HCl}$ and kept at $4^{\circ} \mathrm{C}$ for $\mathrm{MeHg}$. Temperature, $\mathrm{pH}$, conductivity, oxygen concentration, and nitrate, nitrite, ammonium concentrations were measured in a $40 \mathrm{~mL}$ aliquot before the daily water renewal with a multimeter and by spectrophotometry following Permachem protocol, respectively.

\section{CBZ and MeHg analysis}

Water aliquots were enriched $10 \mathrm{x}$ through centrifugal vacuum evaporation at $37^{\circ} \mathrm{C}$ using a Genevac HT Series (SP Scientific). The CBZ concentration in water was quantified using a HighPerformance Liquid Chromatography (HPLC) system (Agilent technologies, 1260 Infinity), consisting of a quaternary pump and a photodiode array detector. A mobile phase containing acetonitrile $(A)$, and ultra-pure water (ALPHA Q $18.2 \mathrm{M} \Omega \cdot \mathrm{cm}^{-1}$ ) with $0.1 \%$ orthophosphoric acid (B), was used to elute the analytes ( $20 \mu \mathrm{L}$ injection volume) on a reverse-phase Agilent Pursuit XRs $5 \mathrm{C}_{18}$ column (5 $\mu \mathrm{m} \times 250 \times 3 \mathrm{~mm}$ ) at $20^{\circ} \mathrm{C}$. The elution was carried out at a flow rate of $0.80 \mathrm{~mL} \cdot \mathrm{min}^{-1}$ with a gradient from $35 / 65 \%$ to $100 / 0 \%$ (v/v) A/B, and CBZ was detected at $214 \mathrm{~nm}$. 
The CBZ concentration in mussels was measured in freeze-dried and ground tissues, resuspended in $10 \mathrm{~mL}$ acetonitrile, $200 \mu \mathrm{L}$-heptane and $2.5 \mathrm{~mL}$ ammonium acetate (0.4 M). After centrifugation (1620 g $10 \mathrm{~min}$ ), the supernatant was recovered, concentrated by a nitrogen flux evaporation at $40{ }^{\circ} \mathrm{C}$ and resuspended in $95 \%$ ultrapure water, $5 \%$ methanol and $0.1 \%$ formic acid (eluent A). Samples of $10 \mu \mathrm{L}$ were injected and analyzed by ultra-performance liquid-chromatography tandem mass spectrometry UPLC MS/MS (Acquity UPLC ${ }^{\circledR}$ Xevo TQ-MS system, Waters). A total running time of $15 \mathrm{~min}$ at $0.4 \mathrm{~mL} \cdot \mathrm{min}^{-1}$ was performed with a gradient of $8 \mathrm{~min} 95 \%$ eluent $A$ and $5 \%$ eluent B (95\% methanol, $5 \%$ ultrapure water and $0.1 \%$ formic acid), $4 \mathrm{~min} 5 \%$ eluent $A$ and $95 \%$ eluent B, 3 min 95\% eluent A and 5\% eluent B. The CBZ concentration in mussels was determined using a standard curve of $0.5,1,2,3,6$ and $12 \mathrm{ng} \mathrm{mL}^{-1} \mathrm{CBZ}$, and by adding an internal standard of deuterated CBZ at $50 \mathrm{ng} \mathrm{mL}^{-1}$. The CBZ recovery of pretreatment method was determined at $79 \pm 8 \%$ $(n=3)$. The analytical quality was verified by analyzing blanks. LOD of $6.8 \mu \mathrm{g} \mathrm{kg}{ }^{-1} \mathrm{dw}$ was calculated.

MeHg concentration in water aliquots and mussels were analyzed by MERX-M (Brooks Rand Instruments). Mussel whole soft tissues were freeze-dried, ground and digested in $30 \% \mathrm{v} / \mathrm{v} \mathrm{HNO}_{3}$ at $60^{\circ} \mathrm{C}$ for $12 \mathrm{~h}$ prior MeHg analysis. MeHg concentration in mussels was determined using a standard curve of $0.5,1,2,10,50,250,500$ and $1000 \mathrm{pg} \mathrm{MeHg}$. The analytical quality was verified by analyzing certified reference material (DORM-4; NRC - CNRC) and blanks. MeHg recovery was determined at $100 \pm 12 \%(n=3)$, and LOD of $0.016 \mathrm{ng}$ MeHg was calculated.

\section{Targeted metabolomics}

Whole individuals were freeze-dried, shells were removed, and soft tissues were weighed, and homogenized into a $900 \mu \mathrm{L}$ mixture of methanol/chloroform $(2 / 1, \mathrm{v} / \mathrm{v})$. The samples were kept at $-20^{\circ} \mathrm{C}$ overnight before adding $600 \mu \mathrm{L}$ of ultrapure water. The samples were vortexed and centrifuged at $4000 \mathrm{~g}\left(10 \mathrm{~min} 4{ }^{\circ} \mathrm{C}\right)$. The upper phase was collected and kept at $-20^{\circ} \mathrm{C}$ until analyzed. Aliquots of $120 \mu \mathrm{L}$ (>90 mg dw), $180 \mu \mathrm{L}(50-90 \mathrm{mg} \mathrm{dw})$ or $220 \mu \mathrm{L}\left(<50 \mathrm{mg} \mathrm{dw}\right.$ ) were vacuum-dried at $32^{\circ} \mathrm{C}$, resuspended in $30 \mu \mathrm{L}$ of methoxyamine hydrochloride $\left(25 \mathrm{mg} \cdot \mathrm{L}^{-1}\right)$ in pyridine and shook at $40^{\circ} \mathrm{C}$ for $60 \mathrm{~min}$. Then, $30 \mu \mathrm{L}$ of $\mathrm{N}$-methyl- $\mathrm{N}$-(trimethylsilyl) trifluoroacetamide was added. After $60 \mathrm{~min}$ incubation at $40^{\circ} \mathrm{C}, 1 \mu \mathrm{L}$ of the sample was injected into the $\mathrm{GC} / \mathrm{MS}$ as described by Thiébaut et al. (2021). After data acquisition, the chromatograms were deconvoluted and analyzed with MassHunter (MS Quantitative Analysis, Quant-My-Way, Agilent). Standard samples, containing 62 reference compounds at $1,2,5,10,20,50,100,200,500,750,1000$, and $1500 \mu \mathrm{M}$ allowed the quantification of 31 metabolites by quadratic calibration (tables A2, A3 and A4), including sugars, amino acids, polyols, organic acids. This approach allowed covering the main metabolic pathways. 
Histology and cytology

For histopathology, gonads, gills and digestive glands were fixed in Bouin's aqueous solution for $24 \mathrm{~h}$ immediately after dissection at D7. Dehydration was performed by successive alcohol baths from 50 to $100^{\circ}$, and samples were placed in butanol for at least $24 \mathrm{~h}$ to permeate all tissues. Samples were impregnated with hot paraffin and embedded by cooling (Paris-Palacios et al., $2000,2003)$. Sections $(5 \mu \mathrm{m})$ were obtained from a Leica microtome, stained with nuclear fast red (NR) and picro-indigo-carmin (PIC) and mounted on glass slides for light microscopy. Gender and gonadic reproductive stage of mussels were determined according to Louis et al. (2020). Three sections of each mussel were observed for the assessment of the frequency and the intensity of potential pathologies resulting from exposures (adapted from Jaffal et al., 2015 and Jacquin et al., 2019) and scored (table A5). A global score of histological perturbations was calculated as the median value of all scores. Mussels presenting parasite(s) weren't analyzed.

For cytology, a piece of the digestive gland was sampled from three mussels for each exposure at D7, immediately cryofixed with an EM ICE High pressure freeze (LEICA) and stored in liquid nitrogen. Then, $100 \mathrm{~nm}$ thick cryosections were freeze-dried, observed with an electronic microscope (JEM - 2100F; JEOL) and image capture were performed with a Digital Micrograph GMS3 (GATAN). The sensitivity of this system allows observations without any contrasting product. Mitochondria in cells of digestive glands were counted and classified into different categories (figure A2). Endoplasmic reticula were also analyzed, and a score was determined based on the frequency and severity of alterations.

\section{Gene expression level}

RNA was extracted with TRI Reagent following Euromedex protocol. Reverse transcription was performed at $42^{\circ} \mathrm{C}$ for $1 \mathrm{~h}$ followed by $3 \mathrm{~min}$ at $95^{\circ} \mathrm{C}$ using the verso cDNA synthesis kit on $400 \mathrm{ng}$ RNA with oligodT primers according to the Thermo Scientific protocol. Quantitative polymerisation chain reactions ( $q P C R$ ) were performed with the Absolute Blue qPCR SYBR Green kit (Thermo Scientific) on $3 \mu \mathrm{L}$ of 1/10 dilution of cDNA reaction, using a CFX96 automaton (BioRad), 15 min at $95^{\circ} \mathrm{C}$, followed by $40 \mathrm{cycles}$ of $10 \mathrm{sec}$ at $95^{\circ} \mathrm{C}$ and $45 \mathrm{sec}$ at $60^{\circ} \mathrm{C}$. Relative gene expression levels of catalase (cat), glutathione-s-transferase (gst), superoxide dismutase (sod) and metallothionein (mt; table A6) were calculated following the $2^{-\Delta \Delta C t}$ method, using actin (act) and ribosomal protein S3 (ps3) as reference genes (Schmittgen and Livak, 2008). 

phenylmethylsulfonyl fluoride and $1 \mathrm{mM} \mathrm{L}$-serine borate as protease inhibitors. After $15 \mathrm{~min}$ at 3000 $\mathrm{g}\left(4^{\circ} \mathrm{C}\right)$, the supernatant $(=$ homogenate $)$ was collected and kept at $-80^{\circ} \mathrm{C}$.

The automated spectrophotometer Gallery (Thermo Scientific) served for the determination of protein concentration, GST activity (Garaud et al., 2016) and lipid hydroperoxide (LOOH) concentration resulting from lipid peroxidation (Arab and Steghens 2004). Protein concentration to normalize enzyme activities was measured at $600 \mathrm{~nm}$ after $5 \mathrm{~min}$ in 1/7 (v/v) of the homogenate by colorimetric method of red pyrogallol, with bovine serum sCal $\left(66.7 \mu \mathrm{g} \cdot \mathrm{L}^{-1}\right)$ for calibration and protein reagents U/CSF from the manufacturer, diluted 50 to 200x (Thermo Scientific). GST activity was measured at $340 \mathrm{~nm}$ for $4 \mathrm{~min}$ in $1 / 40(\mathrm{v} / \mathrm{v})$ of the homogenate by colorimetric method with $0.9 \mathrm{mM}$ 1-chloro-2,4-dinitrobenzene, $1 \mathrm{mM}$ reduced glutathione in $0.1 \mathrm{M}$ phosphate buffer $\mathrm{pH}$ 6.5. LOOH was measured at $620 \mathrm{~nm}$ after $30 \mathrm{~min}$ in 1/46 (v/v) of the homogenate with $139 \mathrm{mM} \mathrm{Fe} \mathrm{II} \mathrm{D-gluconate}$ dihydrate, $240 \mathrm{mM}$ orange xylenol in an acidic solution $\left(\mathrm{H}_{2} \mathrm{SO}_{4} 40 \mathrm{mM}\right.$, glycerol $1.37 \mathrm{M}$, formic acid $20 \mathrm{mM}$ and $\mathrm{NaCl} 0.9 \%)$, using a calibration curve from tert-butyl hydroperoxide at $0.125,0.25,0.5,1$, $2,4,8$ and $16 \mu \mathrm{M}$. $\mathrm{nm}$ for $120 \mathrm{sec}$ in $1 / 100(\mathrm{v} / \mathrm{v})$ of the homogenate by a spectrophotometer (Cary 50, Agilent) with 14 $\mathrm{mM}$ hydrogen peroxide in $50 \mathrm{mM}$ phosphate buffer $\mathrm{pH}$ 7.4, using a calibration curve from purified bovine serum CAT at $1.25,2.5,5,10,15$ and $20 \mathrm{U} \cdot \mathrm{mL}^{-1}$.

SOD activity (Paoletti et al., 1986) was measured in the linear range of the reaction after 20 $\min$ in darkness, at $340 \mathrm{~nm}$ for $30 \mathrm{~min}$ in $1 / 85(\mathrm{v} / \mathrm{v})$ of the homogenate by a spectrophotometer (Spark 10M, TECAN) with $0.1 \mathrm{M}$ EDTA, $0.05 \mathrm{M} \mathrm{MnCl}_{2}, 10 \mathrm{mM} \beta$-mercaptoethanol, $7.5 \mathrm{mM}$ NADH in 50 $\mathrm{mM}$ phosphate buffer $\mathrm{pH}$ 7.4. Concentrations were determined using a calibration curve from purified bovine serum SOD at $0.125,0.25,0.35,0.5$ and $0.7 \mathrm{U} \cdot \mathrm{mL}^{-1}$.

Data interpretation and statistical analysis 
tests in Rstudio software ( $v$ 4.0.3.; $\alpha=5 \%$ ). Student tests vs control were applied if these criteria were met, while Wilcoxon-Mann-Whitney tests vs control were applied if not $(\alpha=5 \%)$.

For metabolomics data, p-values obtained from Student or Wilcoxon-Mann-Whitney tests were corrected through positive false discovery rate (pFDR) procedure (Storey and Tibshirani 2003; Storey 2015) using $c p 4 p$ package. Metabolites were considered as significantly different when $p$ value was $<0.05$ and fold change $(\mathrm{FC})$ values $>1.5$ vs respective control. Metabolites significantly modified were analyzed in Metaboanalyst (http://www.metaboanalyst.ca) with the KEGG database (October 2019). Heat maps were constructed in Genesis (Sturn et al., 2002) comparing $\log _{2^{-}}$ transformed FC normalized by control.

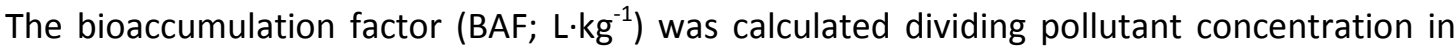
mussels by effective concentration of the pollutant in water. To describe responses, the term synergism, neutral and antagonism were used when the response was higher, similar or lower for the co-exposure than the sum of the individual responses, respectively.

\section{Water parameters}

Concentrations of $\mathrm{CBZ}\left(3.9 \pm 0.6 \mathrm{\mu g} \cdot \mathrm{L}^{-1}\right)$ and $\mathrm{MeHg}\left(280 \pm 20 \mathrm{ng} \cdot \mathrm{L}^{-1}\right)$ were stable among exposures $(n=4)$. Physico-chemical parameters measured from water samples were also stable and similar among exposures: $\mathrm{pH} 8.41 \pm 0.02$, conductivity $530 \pm 30 \mu \mathrm{S} \cdot \mathrm{cm}^{-1}$, oxygen saturation $78.1 \pm 0.4 \%$ $\mathrm{O}_{2}$, nitrate $9.7 \pm 0.6 \mathrm{mg} \cdot \mathrm{L}^{-1}$, nitrite $0.10 \pm 0.01 \mathrm{mg} \cdot \mathrm{L}^{-1}$, ammonium $0.19 \pm 0.03 \mathrm{mg} \cdot \mathrm{L}^{-1}$ and temperature $13.7 \pm 0.1^{\circ} \mathrm{C}$ (figure $\mathrm{A} 3$ ). As water physico-chemical parameters were similar among exposures from D1 to D7, all the observed responses could be attributed to the impact of pollutants.

\section{CBZ and MeHg bioaccumulation}

CBZ bioaccumulation (figure 1) was similar between single and co-exposures both at D1 and D7, showing a BAF of $35 \pm 1$. Compared to the control mussels, MeHg concentration increased $12 x$ at D1 and 63x at D7 in MeHg single exposure, resulting in a BAF of 755 and 3973, respectively. In coexposure, MeHg bioaccumulation increased 23x at D1 and 109x at D7 vs controls, resulting in a BAF of 1471 and 6973, respectively, but showing no statistical difference with single exposure. As such responses were neutral for bioaccumulation and data highlighted a 20-40x and 100-200x higher BAF of MeHg than CBZ in mussel tissues at D1 and D7, respectively. No bioaccumulation of the other 
pollutant was measured in single exposures. MeHg concentration in controls reached $0.017 \pm 0.003$ $\mathrm{mg} \cdot \mathrm{kg}^{-1}$ confirming clean exposure conditions.

\section{Targeted metabolomics}

Metabolites characterized D. polymorpha phenotype at the individual level (Figure 2, table $A 2$ and A3). Only the co-exposure at D7 significantly impacted the metabolome resulting in the decrease of 25 metabolites, involved in 16 metabolic pathways of amino acids, energy metabolism and antioxidant responses (table 1). CBZ exposure at D7 decreased 2.2x the concentration of $\alpha$ aminobutyric acid, involved in cysteine and methionine metabolism. MeHg single exposure and all D1 exposures didn't modulate metabolites significantly. Synergism was observed for metabolomics at D7 when comparing co-exposure with single exposures and were congruent with the higher bioaccumulation observed at D7 vs D1 for $\mathrm{MeHg}$, while CBZ bioaccumulation was similar.

\section{Histology and cytology}

To further understand metabolomic observations at D7, we compared histopathology of gills and digestive glands, because of their direct exposure to the media and detoxifying role in bivalves, respectively (table 2; figures 3 and A4). Exposure to $\mathrm{MeHg}$ and the co-exposure caused a high degree of gill fibrosis, deformation, and alteration: 25 to $50 \%$ of the gills respiratory surface was altered. Besides, 20 to $40 \%$ of digestive tubules showed numerous fibrosis and cell alterations, such as picnotic nucleus, in progress and terminal lysis or necrosis. Because of involution and atresia, 10 to $20 \%$ of digestive tubules appeared non-functional. In these exposures, the infiltration of immune cells and an accumulation of liquid in the tissue evoked edema inflammatory process. As such, alterations observed in gills and digestive glands likely resulted in a reduction of function of those organs. For comparison, control and CBZ caused few alterations in gills and no significant alteration in digestive glands. Responses were neutral for histopathology when comparing the co-exposure with single exposures. Histopathology was congruent with metabolomics for the co-exposure and CBZ exposure, but not for MeHg exposure, as MeHg had significant cellular effects unreflected in metabolomics.

In line with histopathology data, cytology in digestive glands pointed MeHg exposure and coexposure to result in most cells having high grades of alterations, while other cells presented an ultrastructure evoking high metabolic capacity (figures 3 and A4). These cells presented a higher amount of reticulum and mitochondria than healthy cells from control mussels, a large well 
conformed nucleus and nucleolus and no alteration of organelles or membranes, thus these cells were qualified as "hyperactive" cells. The altered cell type presented few and deformed reticulum, mitochondria and nuclei likely related to a low metabolic capacity. More in detail, mitochondrial alterations significantly increased vs control with mitochondrial bodies, cristae malformation or break, inner and outer membrane impairment. Moreover, reticulum cisternae were largely dilated. A reduction of the amount of cisterna and some breaks and dispersion were also observed (figures 3 and A2). Erosion of cilia, and modification of membrane form or thickness in cytoplasmic and nuclear regions was sometimes observed. Exposure to CBZ also resulted in two types of digestive cells: hyperactive and altered cells as described above. The amount of altered type cells in CBZ-exposed mussels varied highly among areas of the digestive gland and among individuals masking any obvious trend. Few cells also appeared hyperactive with important alterations, i.e. presenting both types. In control, $83 \%$ of digestive cells showed ultra-structural patterns typical from healthy cells, i.e. without pathology. Only $10 \pm 4 \%$ non-functional mitochondria and a large amount of well-conformed reticulum cisterns were observed. Responses were neutral for cytology when comparing the coexposure with single exposures. Cytology was congruent with histopathology for the co-exposure and $\mathrm{MeHg}$ exposure, but not for CBZ exposure. These observations together with metabolomics suggested that hyperactive cells efficiently compensated altered cells in MeHg and CBZ exposures, resulting in an unimpacted metabolome in single exposures, but a modified metabolome in the coexposure.

\section{Oxidative stress and defences}

Because both CBZ and MeHg are expected to trigger ROS production, we analyzed oxidative stress and defense endpoints (figure 4). At the transcript level, CBZ significantly upregulated 1.7 and 1.9x $\mathrm{mt}$ gene in gills and digestive glands respectively at $\mathrm{D} 1$, and $1.8 \mathrm{x}$ sod gene in gills at $\mathrm{D} 7$, while it increased 1.4x CAT activity in digestive glands at D7. MeHg significantly upregulated $1.8 x$ cat at D1 and $2 x$ sod at D7 in gills and increased $1.6 x$ and 1.2x SOD activity in gills and digestive glands respectively at D7. Co-exposure also upregulated $2 x \mathrm{mt}$ expression in digestive glands at D1 and increased 1.5x SOD activity and 1.5x CAT activity in gills at D7. GST activity or LOOH concentration wasn't significantly modified here. Data suggested a ROS production by CBZ and MeHg in gills and the digestive gland, suggesting an antagonism on these endpoints in the co-exposure, except for $\mathrm{mt}$ gene expression and SOD activity that were neutral. Effects globally suggested different responses in organs depending on the pollutant and no obvious correlation with bioaccumulation. 
Data here suggested that CBZ alone triggered a low stress level. At D7, cytology of digestive glands revealed (i) the occurrence of cells defined as "hyperactives", with ultrastructure typically linked to an increased metabolism (e.g. higher amount of endoplasmic reticulum, mitochondria and nucleus size higher than control), and (ii) the occurrence of other cells with cytological features of a reduced metabolism and an important rate of alterations (e.g. broken cristae in mitochondria, abnormal nucleus). Concomitantly few damages were observed at the tissue level by histopathology. The link between the ultrastructure of cells and its functions was fully demonstrated by others in most types of cells (Segner and Braunbeck, 1990, 1998; Biagianti-Risbourg, 1997). Ultrastructural perturbations were recognized as a biomarker of interest in ecotoxicology (Segner and Braunbeck, 1990, 1998; Biagianti-Risbourg, 1997). Few studies focused on structure and ultrastructure of cells in bivalves, and to our knowledge no studies investigated CBZ effect at the cytological level (Au et al., 2004). A juxtaposition of cells showing important alterations, and cells showing indications of increased activity (forming a mosaic), was also reported in the liver of fish exposed to copper and procymidone (Paris-Palacios et al., 2000; Paris-Palacios et al., 2003). Authors suggested a compensation of damaged cells by "hyperactive" cells (Paris-Palacios et al., 2000; Paris-Palacios et al., 2003). Similarly, here, damages observed in altered cells appeared efficiently compensated by the increased metabolic activity of the "hyperactive" cells. Consequently, the metabolome was efficiently maintained, except for the significant decrease of $\alpha$-aminobutyric acid amount at D7. In Daphnia magna exposed $48 \mathrm{~h}$ to 1.75 to $14 \mathrm{mg} \cdot \mathrm{L}^{-1} \mathrm{CBZ}$, a significant decrease by 3 to $15 \%$ of alanine, glycine, leucine, proline, serine and tryptophan concentrations, suggested an increase of protein biosynthesis and amino acid metabolism (Kovacevic et al., 2016). In the same line, in 96h post-fertilization larvae of Danio rerio, 24h exposure to $3.54 \mathrm{\mu g} \cdot \mathrm{L}^{-1} \mathrm{CBZ}$ mainly reduced amino acids (Huang et al., 2016). Nonetheless, studies were performed at high CBZ concentrations for the former, and for the latter in juveniles who are more sensitive than adults (Huang et al., 2016; Huang et al., 2017), limiting a direct comparison with our experimental conditions. Besides, here CAT activity increased in digestive glands at D7, without lipid peroxidation, supporting that cellular defenses copped well ROS production by CBZ. For comparison, in Scrobicularia plana, a $96 \mathrm{~h}$ exposure to $3 \mu \mathrm{g} \cdot \mathrm{L}^{-1} \mathrm{CBZ}$ reduced CAT and SOD activities 1.5x in soft tissues, and increased 1.3x lipid peroxidation (Freitas et al., 2015), suggesting that $D$. polymorpha might be more tolerant than S. plana thanks to an efficient defense response. In the same line, here the $\mathrm{mt}$ gene was upregulated in gills and digestive glands at D1. MT is mainly known for its role in metal detoxification but was also described as a ROS scavenger and suspected to have an anti-apoptotic function (Takahashi, 2012). MT content increased 10x in liver of fish Rutilus 
rutilus exposed 4 days to $200 \mu \mathrm{g} \cdot \mathrm{L}^{-1}$ of the fungicide procymidone (Paris-Palacios et al., 2003). As such, MT might be involved in tolerance against ROS in D. polymorpha in our experimental conditions.

\section{MeHg exposure}

Here, MeHg exposure, similarly to CBZ exposure, resulted in cellular damages without impact on the metabolome, supporting that $D$. polymorpha could cope with this stress level thanks to an efficient defense response. Indeed, no metabolite was modulated, while numerous necrosis, altered cells and degenerative alterations in gills and digestive glands such as ciliary erosion, cell necrosis and tissue malformations were observed. The inflammation by $\mathrm{Hg}$ was previously reported in bivalves in several histopathological studies (Bigas et al., 2006; Cappello et al., 2013; Chalghmi et al., 2016; do Amaral et al., 2019). It is considered as nonspecific consequences of physiological adaptation to a stress (Bigas et al., 2006; Cappello et al., 2013; Chalghmi et al., 2016; do Amaral et al., 2019). However, cytological observations here evidenced altered digestive cells, showing damaged membranes and mitochondria. Concomitantly, we observed an increased number of cells presenting a high number of mitochondria and a development of their REG, pointing to a high metabolic activity, likely compensating the loss of activity of damaged cells. Similarly, exposure of Anguilla anguilla 11 days to $50 \mathrm{ng} \cdot \mathrm{L}^{-1} \mathrm{MeHg}$, upregulated (10-500x) genes cox1 and $12 \mathrm{~s}$ involved in mitochondrial metabolism, while altered mitochondria were likely compensated by an increased number of mitochondria observed in muscle fibers by electron microscopy (Claveau et al., 2015). Mitochondria are expected targets of MeHg in animals (Ferreira et al., 2018; Correa et al., 2020). For example, MeHg depolarized mitochondrial membrane in synaptosomes (Hare and Atchinson, 1992). Here, MeHg at D1 also upregulated cat gene expression level in gills and increased SOD activity in digestive glands. MeHg at D7, increased sod gene expression and SOD activity in gills. Data for $\mathrm{MeHg}$ supported a ROS production in tissues not resulting in lipid peroxidation and an efficient antioxidant response in our experimental conditions. An increase of intracellular ROS levels by 1.2 to $1.5 x$ was previously reported in copepods Tigriopus japonicus and Paracyclina nana exposed to 1 to $1000 \mathrm{ng} \cdot \mathrm{L}^{-}$

${ }^{1} \mathrm{MeHg} 24 \mathrm{~h}$, together with an increase of GST activity by 1.3 to $1.5 x$ (Lee et al., 2017a; Lee et al., 2017b). Here, data globally suggested that $\mathrm{MeHg}$ induced cellular damage and altered organelle functions, but cellular compensation and defense responses resulted in tolerance in $D$. polymorpha to $\mathrm{MeHg}$ exposure.

\section{Co-exposure}


Here, the co-exposure in D. polymorpha was the most disturbing for the metabolome at D7, and showed a synergistic response vs single exposures. In contrast to single exposures, in the coexposure hyperactive cells didn't efficiently compensate for damaged cells, resulting in the reduction of 25 of the 31 quantified metabolites. Here, co-exposure also triggered ROS production as shown by increased $\mathrm{mt}$ gene expression level in digestive glands at D1, and CAT and SOD activities in gills at D7. Besides, a $2 x$ decrease of glutamic acid and glycine supported glutathione biosynthesis at D7. Those responses suggested a higher ROS production for co-exposure than single exposures, in line with the known ability of both pollutants to trigger ROS production (Freitas et al., 2015; Lee et al., 2017a; Lee et al., 2017b). Nonetheless, lipid peroxidation wasn't measured here, which supported an efficient antioxidant response maintaining the RedOx balance of $D$. polymorpha in the co-exposure. However, the impact of the co-exposure at D7 wasn't predictable based on the low toxicity level triggered by single exposures. Similarly, in Ruditapes philippinarum, exposure 21 days to $10 \mu \mathrm{g} \cdot \mathrm{L}^{-1} \mathrm{IHg}$ and $3 \mu \mathrm{g} \cdot \mathrm{L}^{-1}$ benzo[a]pyrene resulted in synergistic effects on glutathione content and lipid peroxidation, while GST and CAT activities weren't modified by the co-exposure (Jiang et al., 2019). In contrast, in $R$. philippinarum exposure 7 days to $10 \mu \mathrm{g} \cdot \mathrm{L}^{-1} \mathrm{IHg}$ and $25 \mu \mathrm{g} \cdot \mathrm{L}^{-1}$ microplastics caused antagonistic responses on histological alterations, and no modification of CAT activity, GSH content or lipid peroxidation in gills and digestive glands, compared to single exposures (Sikdokur et al., 2020). Although microplastics are a different type of pollutants likely having distinct modes of action, the number of studies investigating combined effects of pollutants is very low, limiting comparisons with the literature. Here, antioxidant defenses didn't seem directly related to pollutant bioaccumulation, cellular and metabolome impact. As such, data suggested that other molecular toxicity pathways triggered by the co-exposure could contribute to observed damages.

Modulated metabolites were further analyzed to identify additional putative molecular toxicity pathways occurring here. An alteration of tRNA-aminoacyl biosynthesis and the metabolism of several amino acids were observed, suggesting an impact on protein biosynthesis. For example, branched chain amino acids (BCAAs; isoleucine, leucine and valine) were decreased in line with observations in D. magna exposed 48h to 1.75 to $14 \mathrm{mg} \cdot \mathrm{L}^{-1}$ CBZ (Kovacevic et al., 2016). BCAAs are known precursors for the synthesis of stress response proteins in aquatic invertebrates such as chaperon proteins that maintain molecular and cellular functionalities (Calder, 2006). Free amino acids are also known to be central for cell osmoregulation in mollusks (Viant et al., 2003, Kovacevic et al., 2016). The decreased concentrations of free amino acids in the co-exposure here might suggest an osmotic stress of $D$. polymorpha. In adductor muscles of $R$. philippinarum, IHg decreased amino acid concentrations, which was likely compensated by an increase of other osmolytes such as betaine, homarine and taurine (Liu et al., 2011a). Similarly, the increase of amino acids in gills of $R$. 
philippinarum was likely compensated by a decrease of these same osmolytes (Liu et al., 2011b). In both studies, authors hypothesized that IHg disturbed osmoregulation functions, potentially causing an osmotic stress. In the same line, an increase of osmolality, suggesting osmotic perturbation, was measured in the plasma of Solea senegalensis $48 \mathrm{~h}$ after $1 \mathrm{mg} \cdot \mathrm{kg}^{-1} \mathrm{CBZ}$ injection (González-Mira et al., 2016). Here, obvious alterations of gill filaments and digestive cells were observed in D. polymorpha in the co-exposure, which could result from osmoregulation disturbances together with ROS production. However, other analyses beyond the scope of the present work are needed to conclude.

Pathway analysis of metabolites also indicated an alteration of energetic and carbohydrate metabolism, such as galactose and pyruvate metabolism in D. polymorpha co-exposed to CBZ+MeHg. Similarly, cellular and mitochondrial alterations pointed to an alteration of functions essential for the energy metabolism (Rodrigo and Costa 2017; Faggio et al., 2018). Here, glucose, inositol and mannose, glyceric, fumaric and malic acids were significantly reduced, suggesting a higher energy consumption and an increased energy production through alternative pathways, such as the citric cycle. In aquatic invertebrates, stress is known to reshuffle metabolism, i.e. using amino acids to produce energy through an alternative pathway (Sokolova et al., 2012). At higher stress levels, the physiological homeostasis can be altered, eventually resulting in dysregulation of the metabolite fluxes in and among metabolic pathways. In R. philippinarum, exposed $48 \mathrm{~h}$ to $20 \mu \mathrm{g} \cdot \mathrm{L}^{-1} \mathrm{IHg}$ ATP/ADP ratio, succinic and citric acid decreased in adductor muscle, while ATP/ADP ratio, lactic acid and $\alpha$ ketoglutarate increased in gills (Liu et al., 2011a; Liu et al., 2011b). Similarly, in R. philippinarum, 21 days exposure to $2 \mu \mathrm{g} \cdot \mathrm{L}^{-1} \mathrm{IHg}$ decreased $1.5 x$ glycogen in hepatopancreas (Jiang et al., 2019). In $M$. galloprovincialis, exposure $96 \mathrm{~h}$ to $6 \mu \mathrm{g} \cdot \mathrm{L}^{-1} \mathrm{CBZ}$ decreased glycogen and protein contents 1.5 and $1.3 \mathrm{x}$ respectively, while the mitochondrial electron transport system (ETS) increased 1.2x (Oliveira et al., 2017). All these studies highlighted a high impact on the energy metabolism, evidenced by a high energy demand. It would be interesting to measure ETS in the future, as it could be a relevant indicator of metabolic capacity of mussels (Bielen et al., 2016). In sum, both CBZ and MeHg could alter energy metabolism, and have the potential to disrupt physiological homeostasis at high concentration individually. The co-exposure to $\mathrm{CBZ}+\mathrm{MeHg}$ might result in a similar stress level than single exposures at a much higher concentration.

\section{Bioaccumulation and observed effects}

Here, bioaccumulation of MeHg measured in D. polymorpha at D1 and D7 corresponded to values found at moderately ( $\leq 0.4 \mathrm{mg} \cdot \mathrm{kg}^{-1} \mathrm{dw}$ ) and highly contaminated sites ( $\leq 1.9 \mathrm{mg} \cdot \mathrm{kg}^{-1} \mathrm{dw}$ ), respectively. For comparison, MeHg concentration reached $0.4 \mathrm{mg} \cdot \mathrm{kg}^{-1} \mathrm{dw}$ in Cerastoderma glaucum tissues (Dominik et al., 2014) and $0.21 \mathrm{mg} \cdot \mathrm{kg}^{-1} \mathrm{MeHg}$ dw in Crassostrea virginica (Apeti et al., 2012) in 
moderately contaminated sites. Besides, all values were $<0.5 \mathrm{mg} \cdot \mathrm{kg}^{-1} \mathrm{fw}\left(\right.$ i.e. $\left.\sim 2.5 \mathrm{mg} \cdot \mathrm{kg}^{-1} \mathrm{dw}\right)$, the threshold for seafood commercialization in Europe (EC 1881/2006). For CBZ, a BAF of 37 was observed here. Similarly, a BAF of 25 was determined in M. galloprovincialis exposed 20 days to 15.7 $\mu \mathrm{g} \cdot \mathrm{L}^{-1}$ CBZ (Serra-Compte et al., 2018). On the contrary, CBZ bioaccumulation was $10 x$ lower in $D$. polymorpha after 1 to 6 months exposure to $5 \mu \mathrm{g} \cdot \mathrm{L}^{-1} \mathrm{CBZ}$ (Daniele et al., 2017; Magniez et al., 2018) and in bivalves sampled in polluted sites ( $\leq 11 \mu \mathrm{g} \cdot \mathrm{kg}^{-1} \mathrm{dw}$; Almeida et al., 2020). The latter studies didn't use an internal standard, while Serra-Compte et al. (2018) and here did, likely explaining those differences. Further analyses of environmental samples with internal standards are needed to conclude. Metabolites of CBZ (e.g. acridine, 2-hydroxy-CBZ) weren't analyzed here, because previous analysis in $D$. polymorpha suggested their absence after 1 to 6 months of exposure to $5 \mu \mathrm{L} \mathrm{L}^{-1} \mathrm{CBZ}$ (Magniez et al., 2018). Here we hypothesized that the drug parent was mainly causing biological effects.

Biological effects are generally expected to be linked with bioaccumulation (Sijm and Hermens, 2001; Le Guernic et al., 2016; Kershaw and Hall, 2019). Here, bioaccumulation of MeHg in $D$. polymorpha increased from D1 to D7, while CBZ bioaccumulation was similar, but metabolome and defense responses weren't altered after single exposure. As such, bioaccumulation and biological responses didn't seem linearly correlated here. Since bioaccumulation of MeHg and CBZ were similar for all exposures at D7, data supported that CBZ and MeHg impacted similar molecular toxicity pathways. Previous studies also showed that bioaccumulation was unrelated to effects observed. For example, in $R$. philippinarum, co-exposure 21 days to $2 \mu \mathrm{g} \cdot \mathrm{L}^{-1} \mathrm{IHg}$ and $3 \mu \mathrm{g} \cdot \mathrm{L}^{-1}$ benzo[a]pyrene caused lipid peroxidation, while single exposures didn't (Jiang et al., 2019). Besides, single exposures 28 days of $R$. philippinarum to $1 \mu \mathrm{g} \cdot \mathrm{L}^{-1} \mathrm{CBZ}$ and $0.5 \mu \mathrm{g} \cdot \mathrm{L}^{-1} \mathrm{Cd}$ caused lipid peroxidation and altered GST activity, while the co-exposure resulted in a similar bioaccumulation, but unaltered defense responses (Almeida et al., 2018). Contrasting responses in co-exposures underline the need to better understand the molecular toxicity pathways of pollutants in D. polymorpha to improve biomonitoring in complex environments, and anticipate effects.

\section{Conclusion}

Data presented here investigated the toxicity of CBZ and MeHg at 8x and 4x EQS concentrations, respectively in a freshwater bivalve. Single exposures didn't alter the metabolome despite an increased number of altered cells, likely compensated by hyperactive cells. This compensation didn't appear efficient enough for the co-exposure $\mathrm{CBZ}+\mathrm{MeHg}$ at $\mathrm{D7}$, resulting in a decrease of metabolites involved in RedOx, amino acid, osmoregulation and energy metabolism. We attributed these 
responses to similar molecular toxicity pathways induced by CBZ and MeHg. However, such effects were unpredictable based on responses to single exposures, confirming the need to study more in detail molecular toxicity pathways. Indeed, co-exposure to pollutants should be better considered by the legislation and may well modify current EQS. Studies linking bioaccumulation and molecular toxicity pathways of pollutants at environmental concentrations are thus a research priority to better anticipate effects in situ. Further non-targeted analysis (e.g. proteomics, RNAseq) at the individual level and on specific organs will give supplemental clues on the involved molecular toxicity targets, and could help to identify early-warning responses.

\section{Acknowledgements}

We are grateful to the EcoChimie Platform (EcoChim) from UMS OSUR 3343 for access to metabolomics facilities and support. Authors would like to thank Fanny Louis, Olivier Fernandez and Nicolas Borie for their technical help. The authors also benefitted from the French GDR "Aquatic Ecotoxicology" framework which aims at fostering stimulating scientific discussions and collaborations for more integrative approaches.

\section{Funding}

This research was funded by Grand Reims through the Aquasurv Chair, by the French National program EC2CO (Ecosphère Continentale et Côtière) through the CARMA $n^{\circ} 12837$ program and by the SFR Condorcet through the DeMo program.

\section{References}

Aguirre-Martínez, G.V., DelValls, A.T., Martín-Díaz, L.M., 2015. Yes, caffeine, ibuprofen, carbamazepine, novobiocin and tamoxifen have an effect on Corbicula fluminea (Müller, 1774). Ecotoxicology and Environmental Safety 120, 142-154. https://doi.org/10.1016/i.ecoenv.2015.05.036

Almeida, Â., Freitas, R., Calisto, V., Esteves, V.I., Schneider, R.J., Soares, A.M.V.M., Figueira, E., 2015. Chronic toxicity of the antiepileptic carbamazepine on the clam Ruditapes philippinarum. Comparative Biochemistry and Physiology Part C: Toxicology \& Pharmacology 172-173, 26-35. https://doi.org/10.1016/i.cbpc.2015.04.004

Almeida, Â., Calisto, V., Esteves, V.I., Schneider, R.J., Soares, A.M.V.M., Figueira, E., Freitas, R., 2018. Effects of single and combined exposure of pharmaceutical drugs (carbamazepine and cetirizine) and a metal (cadmium) on the biochemical responses of $R$. philippinarum. Aquatic Toxicology 198, 10-19. https://doi.org/10.1016/i.aquatox.2018.02.011

Almeida, Â., Esteves, V.I., Soares, A.M.V.M., Freitas R., 2020. Effects of Carbamazepine in Bivalves: A Review, Reviews of Environmental Contamination and Toxicology. https://doi.org/10.1007/398 202051

Andreu, V., Gimeno-García, E., Pascual, J.A., Vazquez-Roig, P., Picó, Y., 2016. Presence of pharmaceuticals and heavy metals in the waters of a Mediterranean coastal wetland: potential 
interactions and the influence of the environment. Science of the Total Environment 540, 278286. https://doi.org/10.1016/j.scitotenv.2015.08.007

Arab, K., Steghens, J.-P., 2004. Plasma lipid hydroperoxides measurement by an automated xylenol orange method. Analytical Biochemistry 325, 158-163.

https://doi.org/10.1016/i.ab.2003.10.022

Apeti, D.A., Lauenstein, G.G., Evans, D.W., 2012. Recent Status of Total Mercury and Methyl Mercury in the Coastal Waters of the Northern Gulf of Mexico Using Oysters and Sediments from NOAA's Mussel Watch Program. Marine Pollution Bulletin 64 (11): 2399-2408. https://doi.org/10.1016/i.marpolbul.2012.08.006

$\mathrm{Au}$, D.W.T., 2004. The application of histo-cytopathological biomarkers in marine pollution monitoring: a review. Marine Pollution Bulletin 48, 817-834. https://doi.org/10.1016/j.marpolbul.2004.02.032

Beauvais-Flück, R., Gimbert, F., Méhault, O., Cosio, C., 2017. Trophic fate of inorganic and methylmercury in a macrophyte-chironomid food chain. Journal of Hazardous Materials 338, 140-147. https://doi.org/10.1016/i.jhazmat.2017.05.028

Beer, R.F., Sizer, I.W., 1952. A spectrophotometric method for measuring the breakdown of hydrogen peroxide by catalase. J Biol Chem 195 (1), 133-40. PMID: 14938361

Biagianti-Risbourg, S., 1957. Les perturbations (ultra)structurales du foie des poissons utilisées comme biomarqueurs de la qualité sanitaire des milieux aquatiques. In: Lagadic Amiard, J.C., Caquet, T., And Ramande, F., (EDS), Utilisation de biomarqueurs en écotoxicologie, aspects fondamentaux. Masson Pub., Paris, 355-391

Bielen, A., Bošnjak, I., Sepčić, K., 2016. Differences in tolerance to anthropogenic stress between invasive and native bivalves. Sci. Total Environ. 543 (Part A), 449-459. https://doi.org/10.1016/j.scitotenv.2015.11.049

Bigas, M., Durfort, M., Poquet, M., 2006. Cytological response of hemocytes in the European flat oyster, Ostrea edulis, experimentally exposed to mercury. BioMetals 19, 659-673. https://doi.org/10.1007/s10534-006-9003-5

Binelli, A., Della Torre, C., Magni, S., Parolini, M., 2015. Does zebra mussel (Dreissena polymorpha) represent the freshwater counterpart of Mytilus in ecotoxicological studies? A critical review. Environmental Pollution 196, 386-403. https://doi.org/10.1016/i.envpol.2014.10.023

Brandts, I., Teles, M., Gonçalves, A.P., Barreto, A., Franco-Martinez, L., Tvarijonaviciute, A., Martins, M.A., Soares, A.M.V.M., Tort, L., Oliveira, M., 2018. Effects of nanoplastics on Mytilus galloprovincialis after individual and combined exposure with carbamazepine. Science of The Total Environment 643, 775-784. https://doi.org/10.1016/j.scitotenv.2018.06.257

Bravo, A.G., Cosio, C., Amouroux, D., Zopfi, J., Chevalley, P.-A., Spangenberg, J.E., Ungureanu, V.-G., Dominik, J., 2014. Extremely elevated methylmercury levels in water, sediment and organisms in a Romanian reservoir affected by release of mercury from a chlor-alkali plant. Water Research 49, 391-405. https://doi.org/10.1016/i.watres.2013.10.024

Brinke B., 2017. Toxicogenomics in environmental science. In vitro Environmental Toxicology Concepts, Application and Assessment, Reifferscheid et al, Eds Springer International Publishing, 159.

Calder, P.C., 2006. Branched-Chain Amino Acids and Immunity. The Journal of Nutrition 136, 288S293S. https://doi.org/10.1093/jn/136.1.288S

Calisto, V., Bahlmann, A., Schneider, R.J., Esteves, V.I., 2011. Application of an ELISA to the quantification of carbamazepine in ground, surface and wastewaters and validation with LCMS/MS. Chemosphere 84 (11): 1708-15. https://doi.org/10.1016/j.chemosphere.2011.04.072

Cappello, T., Maisano, M., D’Agata, A., Natalotto, A., Mauceri, A., Fasulo, S., 2013. Effects of environmental pollution in caged mussels (Mytilus galloprovincialis). Marine Environmental Research 91, 52-60. https://doi.org/10.1016/j.marenvres.2012.12.010

Cardoso, P.G., Grilo, T.F., Pereira, E., Duarte, A.C., Pardal, M.A., 2013. « Mercury Bioaccumulation and Decontamination Kinetics in the Edible Cockle Cerastoderma Edule ». Chemosphere 90 (6): 1854-59. https://doi.org/10.1016/j.chemosphere.2012.10.005 
Celiz, M.D., Perez, S., Barcelo, D., Aga, D.S., 2009. Trace Analysis of Polar Pharmaceuticals in Wastewater by LC-MS-MS: Comparison of Membrane Bioreactor and Activated Sludge Systems. Journal of Chromatographic Science 47, 19-25. https://doi.org/10.1093/chromsci/47.1.19

Chalghmi, H., Bourdineaud, J.-P., Haouas, Z., Gourves, P.-Y., Zrafi, I., Saidane-Mosbahi, D., 2016. Transcriptomic, Biochemical, and Histopathological Responses of the Clam Ruditapes decussatus from a Metal-Contaminated Tunis Lagoon. Archives of Environmental Contamination and Toxicology 70, 241-256. https://doi.org/10.1007/s00244-015-0185-0

Chen, H., Zha, J., Liang, X., Li, J., Wang, Z., 2014. Effects of the human antiepileptic drug carbamazepine on the behavior, biomarkers, and heat shock proteins in the Asian clam Corbicula fluminea. Aquatic Toxicology 155, 1-8. https://doi.org/10.1016/j.aquatox.2014.06.001

Clara, M., Strenn, B., Kreuzinger, N., 2004. Carbamazepine as a possible anthropogenic marker in the aquatic environment: investigations on the behaviour of Carbamazepine in wastewater treatment and during groundwater infiltration. Water Research 38, 947-954. https://doi.org/10.1016/j.watres.2003.10.058

Claveau, J., Monperrus, M., Jarry, M., Baudrimont, M., Gonzalez, P., Cavalheiro, J., Mesmer-Dudons, N., Bolliet, V., 2015. Methylmercury effects on migratory behaviour in glass eels (Anguilla anguilla): An experimental study using isotopic tracers. Comparative Biochemistry and Physiology Part C: Toxicology \& Pharmacology 171, 15-27. https://doi.org/10.1016/j.cbpc.2015.03.003

Coppola, F., Almeida, Â., Henriques, B., Soares, A.M.V.M., Figueira, E., Pereira, E., Freitas, R., 2017. Biochemical impacts of $\mathrm{Hg}$ in Mytilus galloprovincialis under present and predicted warming scenarios. Science of The Total Environment 601-602, 1129-1138. https://doi.org/10.1016/i.scitotenv.2017.05.201

Correa, M.G., Bittencourt, L.O., Nascimento, P.C., Ferreira, R.O., Araga, W.A.B., Silva, M.C.F., GomesLeal, W., Fernandes, M.S., Dionizio, A., Buzalaf, M.R., Crespo-Lopez, M.E., Lima, R.R., 2020. Spinal cord neurodegeneration after inorganic mercury long-term exposure in adult rats: Ultrastructural, proteomic and biochemical damages associated with reduced neuronal density. Ecotox Env Saf 191, 110159. https://doi.org/10.1016/j.ecoenv.2019.110159

Daniele, G., Fieu, M., Joachim, S., Bado-Nilles, A., Beaudouin, R., Baudoin, P., James-Casas, A., Andres, S., Bonnard, M., Bonnard, I., Geffard, A., Vulliet, E., 2017. Determination of Carbamazepine and 12 Degradation Products in Various Compartments of an Outdoor Aquatic Mesocosm by Reliable Analytical Methods Based on Liquid Chromatography-Tandem Mass Spectrometry. Environmental Science and Pollution Research 24 (20), 16893-904. https://doi.org/10.1007/s11356-017-9297-6

Dominik, J., Tagliapietra, D., Bravo, A.G., Sigovini, M., Spangenberg, J.E., Amouroux, D., Zonta, R., 2014. Mercury in the Food Chain of the Lagoon of Venice, Italy. Marine Pollution Bulletin 88 (1-2): 194-206. https://doi.org/10.1016/j.marpolbul.2014.09.005

do Amaral, Q.D.F., Da Rosa, E., Wronski, J.G., Zuravski, L., Querol, M.V.M., dos Anjos, B., de Andrade, C.F.F., Machado, M.M., de Oliveira, L.F.S., 2019. Golden mussel (Limnoperna fortunei) as a bioindicator in aquatic environments contaminated with mercury: Cytotoxic and genotoxic aspects. Science of The Total Environment 675, 343-353. https://doi.org/10.1016/i.scitotenv.2019.04.108

ETOX, 2011. "Datenbank für ökotoxikologische Wirkungsdaten und Qualitätsziele." from http://webetox.uba.de/webETOX/index.do (12/10/2021)

Faggio, C., Tsarpali, V., Dailianis, S., 2018. Mussel digestive gland as a model tissue for assessing xenobiotics: An overview. Science of The Total Environment 636, 220-229. https://doi.org/10.1016/j.scitotenv.2018.04.264

Ferreira, F.F., Nazari, E.M., Muller, Y.M.R., 2018. MeHg causes ultrastructural changes in mitochondria and autophagy in the spinal cord cells of chicken embryo. J Toxicol, 2018, 8460490. https://doi.org/10.1155/2018/8460490 
Franzellitti, S., Fabbri, E., 2006. Cytoprotective responses in the Mediterranean mussel exposed to $\mathrm{Hg} 2+$ and $\mathrm{CH} 3 \mathrm{Hg}+$. Biochemical and Biophysical Research Communications 351, 719-725. https://doi.org/10.1016/i.bbrc.2006.10.089

Franzellitti, S., Balbi, T., Montagna, M., Fabbri, R., Valbonesi, P., Fabbri, E., Canesi, L., 2019. Phenotypical and molecular changes induced by carbamazepine and propranolol on larval stages of Mytilus galloprovincialis. Chemosphere 234, 962-970. https://doi.org/10.1016/j.chemosphere.2019.06.045

Freitas, R., Almeida, Â., Calisto, V., Velez, C., Moreira, A., Schneider, R.J., Esteves, V.I., Wrona, F.J., Soares, A.M.V.M., Figueira, E., 2015. How life history influences the responses of the clam Scrobicularia plana to the combined impacts of carbamazepine and $\mathrm{pH}$ decrease. Environmental Pollution 202, 205-214. https://doi.org/10.1016/i.envpol.2015.03.023

Gagnaire, B., Thomas-Guyon, H., Renault, T., 2004. In vitro effects of cadmium and mercury on Pacific oyster, Crassostrea gigas (Thunberg), haemocytes, Fish \& Shellfish Immunology, 16 (4), 501512. https://doi.org/10.1016/j.fsi.2003.08.007

Garaud, M., Auffan, M., Devin, S., Felten, V., Pagnout, C., Pain-Devin, S., Proux, O., Rodius, F., Sohm, B., Giamberini, L., 2016. « Integrated Assessment of Ceria Nanoparticle Impacts on the Freshwater Bivalve Dreissena Polymorpha ». Nanotoxicology 10 (7): 935-44. https://doi.org/10.3109/17435390.2016.1146363

González-Mira, A., Varó, I., Solé, M., Torreblanca, A., 2016. Drugs of environmental concern modify Solea senegalensis physiology and biochemistry in a temperature-dependent manner. Environ Sci Pollut Res 23, 20937-20951. https://doi.org/10.1007/s11356-016-7293-x

Hani, Y.M.I., Prud'Homme, S.M., Nuzillard, J.-M., Bonnard, I., Robert, C., Nott, K., Ronkart, S., Dedourge-Geffard, O., Geffard, A., 2021. 1H-NMR metabolomics profiling of zebra mussel (Dreissena polymorpha): A field-scale monitoring tool in ecotoxicological studies. Environmental Pollution 270, 116048. https://doi.org/10.1016/i.envpol.2020.116048

Hare, M. F., Atchison, W. D., 1992. Comparative action of methylmercury and divalent inorganic mercury on nerve terminal and intraterminal mitochondrial membrane potentials. J Pharmacol Exp Ther 261, 166-72.

Huang, S.S.Y., Benskin, J.P., Chandramouli, B., Butler, H., Helbing, C.C., Cosgrove, J.R., 2016. Xenobiotics Produce Distinct Metabolomic Responses in Zebrafish Larvae (Danio rerio ). Environ. Sci. Technol. 50, 6526-6535. https://doi.org/10.1021/acs.est.6b01128

Huang, S.S.Y., Benskin, J.P., Veldhoen, N., Chandramouli, B., Butler, H., Helbing, C.C., Cosgrove, J.R., 2017. A multi-omic approach to elucidate low-dose effects of xenobiotics in zebrafish ( Danio rerio ) larvae. Aquatic Toxicology 182, 102-112. https://doi.org/10.1016/i.aquatox.2016.11.016

Jacquin, L., Gandar, A., Aguirre-Smith, M., Perrault, A., Hénaff, M.L., Jong, L.D., Paris-Palacios, S., Laffaille, P., Jean, S., 2019. High temperature aggravates the effects of pesticides in goldfish. Ecotoxicology and Environmental Safety 172, 255-264. https://doi.org/10.1016/j.ecoenv.2019.01.085

Jaffal, A., Betoulle, S., Biagianti-Risbourg, S., Terreau, A., Sanchez, W., Paris-Palacios, S., 2015. Heavy metal contamination and hepatic toxicological responses in brown trout (Salmo trutta) from the Kerguelen Islands. Polar Research 34, 22784. https://doi.org/10.3402/polar.v34.22784

Jaumot, J., Navarro, A., Faria, M., Barata, C., Tauler, R., Piña, B., 2015. qRT-PCR evaluation of the transcriptional response of zebra mussel to heavy metals. BMC Genomics 16. https://doi.org/10.1186/s12864-015-1567-4

Jiang, W., Fang, Jianguang, Gao, Y., Du, M., Fang, Jinghui, Wang, X., Li, F., Lin, F., Jiang, Z., 2019. Biomarkers responses in Manila clam, Ruditapes philippinarum after single and combined exposure to mercury and benzo[a]pyrene. Comparative Biochemistry and Physiology Part C: Toxicology \& Pharmacology 220, 1-8. https://doi.org/10.1016/j.cbpc.2019.02.010

Kase R. 2010. Stoffdatenblattentwurf für Carbamazepin (Stand 15/02/2010; update 30/04/2010). Kershaw, J.L., Hall, A.J., 2019. Mercury in cetaceans: Exposure, bioaccumulation and toxicity. Science of the Total Environment 694, 133683. https://doi.org/10.1016/j.scitotenv.2019.133683 
Kovacevic, V., Simpson, A.J., Simpson, M.J., 2016. 1 H NMR-based metabolomics of Daphnia magna responses after sub-lethal exposure to triclosan, carbamazepine and ibuprofen. Comparative Biochemistry and Physiology Part D: Genomics and Proteomics 19, 199-210. https://doi.org/10.1016/j.cbd.2016.01.004

Lam, M.W., Young, C.J., Brain, R.A., Johnson, D.J., Hanson, M.A., Wilson, C.J., Richards, S.M., Solomon, K.R., Mabury, S.A., 2004. Aquatic persistence of eight pharmaceuticals in a microcosm study. Environmental Toxicology and Chemistry 23(6), 1431-1440. https://doi.org/10.1897/03-421

Le Guernic, A., Sanchez, W., Bado-Nilles, A., Palluel, O., Turies, C., Chadili, E., Cavalié, I., Delahaut, L., Adam-Guillermin, C., Porcher, J.-M., Geffard, A., Betoulle, S., Gagnaire, B., 2016. In situ effects of metal contamination from former uranium mining sites on the health of the three-spined stickleback (Gasterosteus aculeatus, L.). Ecotoxicology 25(6), 1234-59. https://doi.org/10.1007/s10646-016-1677-z

Lee, Y.H., Kang, H.-M., Kim, D.-H., Wang, M., Jeong, C.-B., Lee, J.-S., 2017a. Adverse effects of methylmercury (MeHg) on life parameters, antioxidant systems, and MAPK signaling pathways in the copepod Tigriopus japonicus. Aquatic Toxicology 184, 133-141. https://doi.org/10.1016/i.aquatox.2017.01.010

Lee, Y.H., Kim, D.-H., Kang, H.-M., Wang, M., Jeong, C.-B., Lee, J.-S., 2017b. Adverse effects of methylmercury (MeHg) on life parameters, antioxidant systems, and MAPK signaling pathways in the rotifer Brachionus koreanus and the copepod Paracyclopina nana. Aquatic Toxicology 190, 181-189. https://doi.org/10.1016/j.aquatox.2017.07.006

Liu, X., Zhang, L., You, L., Cong, M., Zhao, J., Wu, H., Li, C., Liu, D., Yu, J., 2011a. Toxicological responses to acute mercury exposure for three species of Manila clam Ruditapes philippinarum by NMR-based metabolomics. Environmental Toxicology and Pharmacology 31, 323-332. https://doi.org/10.1016/i.etap.2010.12.003

Liu, X., Zhang, L., You, L., Yu, J., Zhao, J., Li, L., Wang, Q., Li, F., Li, C., Liu, D., Wu, H., 2011b. Differential toxicological effects induced by mercury in gills from three pedigrees of Manila clam Ruditapes philippinarum by NMR-based metabolomics. Ecotoxicology 20, 177-186. https://doi.org/10.1007/s10646-010-0569-x

Louis, F., Devin, S., Giambérini, L., Potet, M., David, E., Pain-Devin, S., 2019. Energy allocation in two dreissenid species under metal stress. Environmental Pollution 245, 889-897. https://doi.org/10.1016/i.envpol.2018.11.079

Louis, F., Rocher, B., Barjhoux, I., Bultelle, F., Dedourge-Geffard, O., Gaillet, V., Bonnard, I., Delahaut, L., Pain-Devin, S., Geffard, A., Paris-Palacios, S., David, E., 2020. Seasonal monitoring of cellular energy metabolism in a sentinel species, Dreissena polymorpha (bivalve): Effect of global change? Science of the Total Environment 725, 138450. https://doi.org/10.1016/j.scitotenv.2020.138450

Magniez, G., Franco, A., Geffard, A., Rioult, D., Bonnard, I., Delahaut, L., Joachim, S., Daniele, G., Vulliet, E., Porcher, J.-M., Bonnard, M., 2018. Determination of a new index of sexual maturity (ISM) in zebra mussel using flow cytometry: interest in ecotoxicology. Environmental Science and Pollution Research 25, 11252-11263. https://doi.org/10.1007/s11356-017-9256-2

Martin-Diaz, L., Franzellitti, S., Buratti, S., Valbonesi, P., Capuzzo, A., Fabbri, E., 2009. Effects of environmental concentrations of the antiepilectic drug carbamazepine on biomarkers and cAMP-mediated cell signaling in the mussel Mytilus galloprovincialis. Aquatic Toxicology 94, 177-185. https://doi.org/10.1016/j.aquatox.2009.06.015

Metcalfe, C.D., Koenig, B.G., Bennie, D.T., Servos, M., Ternes, T.A., Hirsch, R., 2009. Occurrence of neutral and acidic drugs in the effluents of Canadian sewage exposure plants. Environmental toxicology and chemistry 22 (12): 2872-80. https://doi.org/10.1897/02-469

Metian, M., Pouil, S., Dupuy, C., Teyssié, J.-L., Warnau, M., Bustamante, P., 2020. Influence of food (ciliate and phytoplankton) on the trophic transfer of inorganic and methylmercury in the Pacific cupped oyster Crassostrea gigas. Environmental Pollution 257, 113503. https://doi.org/10.1016/i.envpol.2019.113503 
Miao, X.-S., Yang, J.-J., Metcalfe, C.D., 2005. Carbamazepine and Its Metabolites in Wastewater and in Biosolids in a Municipal Wastewater Exposure Plant. Environ. Sci. Technol. 39, 7469-7475. https://doi.org/10.1021/es050261e

Minamata International Convention, 2013. https://www.mercuryconvention.org/en (12/10/2021)

Moermond, C.T.A., 2014. Environmental risk limits for pharmaceuticals. National Institute for Public Health and the Environment (Netherlands). Available at www.rivm.nl/en (12/10/2021)

Navarro, A., Faria, M., Barata, C., Piña, B., 2011. Transcriptional response of stress genes to metal exposure in zebra mussel larvae and adults. Environmental Pollution 159, 100-107. https://doi.org/10.1016/i.envpol.2010.09.018

Navarro, A., Weißbach, S., Faria, M., Barata, C., Piña, B., Luckenbach, T., 2012. Abcb and Abcc transporter homologs are expressed and active in larvae and adults of zebra mussel and induced by chemical stress. Aquatic Toxicology 122-123, 144-152. https://doi.org/10.1016/i.aquatox.2012.06.008

Oldenkamp, R., Beusen, A.H.W., Huijbregts, M.A.J., 2019. Aquatic risks from human pharmaceuticals - modelling temporal trends of carbamazepine and ciprofloxacin at the global scale. Environmental Research Letters 14, 034003. https://doi.org/10.1088/1748-9326/ab0071

Oliveira, P., Almeida, Â., Calisto, V., Esteves, V.I., Schneider, R.J., Wrona, F.J., Soares, A.M.V.M., Figueira, E., Freitas, R., 2017. Physiological and biochemical alterations induced in the mussel Mytilus galloprovincialis after short and long-term exposure to carbamazepine. Water Research 117, 102-114. https://doi.org/10.1016/j.watres.2017.03.052

Pain-Devin, S., Cossu-Leguille, C., Geffard, A., Giambérini, L., Jouenne, T., Minguez, L., Naudin, B., Parant, M., Rodius, F., Rousselle, P., Tarnowska, K., Daguin-Thiébaut, C., Viard, F., Devin, S., 2014. Towards a better understanding of biomarker response in field survey: A case study in eight populations of zebra mussels. Aquatic Toxicology 155, 52-61. http://dx.doi.org/10.1016/j.aquatox.2014.06.008

Paoletti, F., Aldinucci, D., Mocali, A., Caparrini, A., 1986. A sensitive spectrophotometric method for the determination of superoxide dismutase activity in tissue extracts. Anal. Biochem., 154 (2), pp. 536-541. https://doi.org/10.1016/0003-2697(86)90026-6

Paris-Palacios, S., Biagianti-Risbourg, S., Vernet, G., 2000. Biochemical and (ultra)structural hepatic perturbations of Brachydanio rerio (Teleostei, Cyprinidae) exposed to two sublethal concentrations of copper sulfate. Aquatic Toxicology 50, 109-124. https://doi.org/10.1016/S0166-445X(99)00090-9

Paris-Palacios, S., Biagianti-Risbourg, S., Vernet, G., 2003. Metallothionein induction related to hepatic structural perturbations and antioxidative defenses in roach (Rutilus rutilus) exposed to the fungicide promycidone. Biomarkers 8 (2), 128-141. http://doi.org/10.1080/1354750021000050511

Parisi, M.G., Pirrera, J., La Corte, C., Dara, M., Parrinello, D., Cammarata, M., 2021. Effects of organic mercury on Mytilus galloprovincialis hemocyte function and morphology. J Comp Physiol B 191, 143-158. https://doi.org/10.1007/s00360-020-01306-0

Prud'homme, S.M., Hani, Y.M.I., Cox, N., Lippens, G., Nuzillard, J.-M., Geffard, A., 2020. The Zebra Mussel (Dreissena polymorpha) as a Model Organism for Ecotoxicological Studies: A Prior $1 \mathrm{H}$ NMR Spectrum Interpretation of a Whole Body Extract for Metabolism Monitoring. Metabolites 10, 256. https://doi.org/10.3390/metabo10060256

Pytharopoulou, S., Kournoutou, G.G., Leotsinidis, M., Georgiou, C.D., Kalpaxis, D.L., 2013. Dysfunctions of the translational machinery in digestive glands of mussels exposed to mercury ions. Aquatic Toxicology 134-135, 23-33. https://doi.org/10.1016/j.aquatox.2013.02.014

Rana, M.N., Tangpong, J., Rahman, Md.M., 2018. Toxicodynamics of Lead, Cadmium, Mercury and Arsenic- induced kidney toxicity and exposure strategy: A mini review. Toxicology Reports 5, 704-713. https://doi.org/10.1016/j.toxrep.2018.05.012

Rodrigo, A.P., Costa, P.M., 2017. The Role of the Cephalopod Digestive Gland in the Storage and Detoxification of Marine Pollutants. Front. Physiol. 8, 232. https://doi.org/10.3389/fphys.2017.00232 
Sacher, F., Lange, F.T., Brauch, H.J., Blankenhorn, I., 2001. Pharmaceuticals in groundwaters: analytical methods and results of a monitoring program in Baden-Württemberg, Germany. Journal of chromatography A 938 (1-2): 199-210. https://doi.org/10.1016/S00219673(01)01266-3

Schmittgen, T.D., Livak, K.J., 2008. Analyzing real-time PCR data by the comparative CT method. Nat Protoc 3, 1101-1108. https://doi.org/10.1038/nprot.2008.73

Segner, H., Braunbeck, T., 1990. Qualitative and quantitative assessment of the response of milkfish Chanos chanos, fry to low-level copper exposure. In: Perkins, F.O., Cheng, T.C. (Eds), Pathology in Marine Science. Academic Press, San Diego, USA, 347-368.

Segner, H., Braunbeck, T., 1998. Cellular response profile to chemical stress. Ecotoxicology 3, 521569.

Serra-Compte, A., Maulvault, A.L., Camacho, C., Álvarez-Muñoz, D., Barceló, D., Rodríguez-Mozaz, S., Marques, A., 2018. Effects of water warming and acidification on bioconcentration, metabolization and depuration of pharmaceuticals and endocrine disrupting compounds in marine mussels (Mytilus galloprovincialis). Environmental Pollution 236, 824-834. https://doi.org/10.1016/j.envpol.2018.02.018

Sıkdokur, E., Belivermiş, M., Sezer, N., Pekmez, M., Bulan, Ö.K., Kılıç, Ö., 2020. Effects of microplastics and mercury on manila clam Ruditapes philippinarum: Feeding rate, immunomodulation, histopathology and oxidative stress. Environmental Pollution 262, 114247. https://doi.org/10.1016/j.envpol.2020.114247

Sijm, D.T.H.M., Hermens, J.L.M., 2001. Internal effect concentration: link between bioaccumulation and ecotoxicity for organic chemicals. Bioaccumulation - New Aspects and Developments. The Handbook of Environmental Chemistry (Vol. 2 Series: Reactions and Processes), vol 2J. Springer, Berlin, Heidelberg. https://doi.org/10.1007/10503050 2

Sokolova, I.M., Frederich, M., Bagwe, R., Lannig, G., Sukhotin, A.A., 2012. Energy homeostasis as an integrative tool for assessing limits of environmental stress tolerance in aquatic invertebrates. Marine Environmental Research 79, 1-15. https://doi.org/10.1016/j.marenvres.2012.04.003

Storey, J.D. and Tibshirani, R., 2003. Statistical significance for genomewide studies. Proceedings of the National Academy of Sciences, 100(16):9440-9445. https://doi.org/10.1073/pnas.1530509100

Storey, J.D., 2015. qvalue: Q-value estimation for false discovery rate control. R package version 2.0.0, http://qvalue.princeton.edu/, http://github.com/idstorey/qvalue (12/10/2021)

Sturn, A., Quackenbush, J., Trajanoski, Z., 2002. Genesis: cluster analysis of microarray data. Bioinformatics 18(1):207-8. https://doi.org/10.1093/bioinformatics/18.1.207

Takahashi, S., 2012. Molecular functions of metallothionein and its role in hematological malignancies. J Hematol Oncol 5, 41. https://doi.org/10.1186/1756-8722-5-41

Thiébaut, G., Tarayre, M., Jambon, O., Le Bris, N., Colinet, H., Renault, D., 2021. Variation of thermal plasticity for functional traits between populations of an invasive aquatic plant from two climatic regions. Hydrobiologia 848, 2077-2091. https://doi.org/10.1007/s10750-020-04452-2

Vaux, D.L., Fidler, F., Cumming, G., 2012. Replicates and repeats-what is the difference and is it significant? EMBO reports 13 (4), 291-296. https://doi.org/10.1038/embor.2012.36

Velez, C., Freitas, R., Antunes, S.C., Soares, A.M.V.M., Figueira, E., 2016. Clams sensitivity towards As and $\mathrm{Hg}$ : A comprehensive assessment of native and exotic species. Ecotoxicology and Environmental Safety 125, 43-54. https://doi.org/10.1016/i.ecoenv.2015.11.030

Viant, M.R., Rosenblum, E.S., Tjeerdema, R.S., 2003. NMR-Based Metabolomics: a powerful approach for characterizing the effects of environmental stressors on organism health. Environ Sci Technol 37:4982-4989. https://doi.org/10.1021/es034281x

Yang, L., Zhang, Y., Wang, F., Luo, Z., Guo, S., Strähle, U., 2020. Toxicity of mercury: Molecular evidence. Chemosphere 245, 125586. https://doi.org/10.1016/j.chemosphere.2019.125586 
Table 1: List of metabolic pathways significantly modulated at D7 in soft tissues of $D$. polymorpha

855 exposed to $3.9 \pm 0.6 \mu \mathrm{g} \cdot \mathrm{L}^{-1} \mathrm{CBZ}, 280 \pm 20 \mathrm{ng} \cdot \mathrm{L}^{-1} \mathrm{MeHg}$ and $\mathrm{CBZ}+\mathrm{MeHg}$.

\begin{tabular}{lll}
\hline & Impacted metabolic pathways at D7 & p-value \\
\hline CBZ & Cysteine and methionine metabolism & 0.021 \\
MeHg & - & - \\
CBZ + MeHg & tRNA-aminoacyl biosynthesis & $8.4 \mathrm{e}^{-15}$ \\
& Biosynthesis of branched chain amino acids BCAAs & $3.0 \mathrm{e}^{-6}$ \\
& Arginine biosynthesis & $4.0 \mathrm{e}^{-5}$ \\
& Glyoxylate and dicarboxylate metabolism & $8.7 \mathrm{e}^{-5}$ \\
& Alanine, aspartate and glutamate metabolism & $7.1 \mathrm{e}^{-4}$ \\
Glycine, serine and threonine metabolism & 0.001 \\
Galactose metabolism & 0.008 \\
Glutathione metabolism & 0.008 \\
Cysteine and methionine metabolism & 0.013 \\
Arginine and proline metabolism & 0.019 \\
Degradation of BCAAs & 0.022 \\
Histidine metabolism & 0.024 \\
Biosynthesis of neomycin, kanamycin and gentamicin & 0.031 \\
Pantothenate and CoA biosynthesis & 0.033 \\
Citrate cycle & 0.037 \\
Pyruvate metabolism & 0.044 \\
\hline
\end{tabular}

856 
859 Table 2: Alteration scores determined by histological and cytological observations after exposure to $8603.9 \pm 0.6 \mu \mathrm{g} \cdot \mathrm{L}^{-1} \mathrm{CBZ}, 280 \pm 20 \mathrm{ng} \cdot \mathrm{L}^{-1} \mathrm{MeHg}$ and $\mathrm{CBZ}+\mathrm{MeHg}$ at $\mathrm{D} 7$ in gills and digestive glands of $D$. 861 polymorpha.

\begin{tabular}{lcccc}
\hline & Control & $\mathrm{CBZ}$ & $\mathrm{MeHg}$ & $\mathrm{CBZ}+\mathrm{MeHg}$ \\
\hline Histology & & & & \\
$\quad$ Gills & $0.7 \pm 0.2$ & $0.9 \pm 0.1$ & $2.9 \pm 0.1$ & $2.0 \pm 0.5$ \\
$\quad \begin{array}{l}\text { Digestive glands } \\
\text { Cytology of digestive cells }\end{array}$ & $0.5 \pm 0.0$ & $0.5 \pm 0.0$ & $2.2 \pm 0.2$ & $3.0 \pm 0.0$ \\
$\quad \begin{array}{l}\text { General aspect } \\
\quad \text { Healthy }\end{array}$ & $83 \%$ & $0 \%$ & $11 \%$ & $11 \%$ \\
$\quad$ Altered & $11 \%$ & $60 \%$ & $86 \%$ & $88 \%$ \\
$\quad$ Hyperactive & $6 \%$ & $53 \%$ & $29 \%$ & $19 \%$ \\
$\quad \begin{array}{l}\text { Mitochondria } \\
\quad \text { Altered }\end{array}$ & $30 \pm 5 \%$ & $50 \pm 20 \%$ & $70 \pm 20 \%$ & $60 \pm 10 \%$ \\
$\quad$ Mitochondrial & $12 \pm 7 \%$ & $13 \pm 8 \%$ & $43 \pm 24 \%$ & $34 \pm 14 \%$ \\
$\quad$ Reticulum & & & & \\
$\quad$ Alteration score & $0.4 \pm 0.3$ & $1.0 \pm 0.4$ & $1.9 \pm 0.5$ & $2.1 \pm 0.3$ \\
\hline
\end{tabular}

862

863 
864 Figure 1: Bioaccumulation and bioaccumulation factor (BAF $\mathrm{L}^{\mathrm{kg}} \mathrm{g}^{-1}$ ) of $\mathrm{CBZ}(\mathrm{A})$ and $\mathrm{MeHg}(\mathrm{B})$ in $D$. 865 polymorpha soft tissues at D1 (light) and D7 (dark), exposed to $3.9 \pm 0.6 \mu \mathrm{g} \cdot \mathrm{L}^{-1} \mathrm{CBZ}, 280 \pm 20 \mathrm{ng} \cdot \mathrm{L}^{-1}$ 866 MeHg and the co-exposure (mean \pm SEM, $n=3$ animals; ${ }^{*} p<0.05$ vs control).

868 Figure 2: Log-2 fold change profiles of metabolites at D1 and D7 in soft tissues of D. polymorpha 869 exposed to $3.9 \pm 0.6 \mu \mathrm{g} \cdot \mathrm{L}^{-1} \mathrm{CBZ}, 280 \pm 20 \mathrm{ng} \cdot \mathrm{L}^{-1} \mathrm{MeHg}$ and the co-exposure vs controls ( $\mathrm{n}=8$ animals; $870 * p<0.05$ and $F(>1.5)$.

872 Figure 3: Optic ( $A$ to $H$ ) and electronic ( $I$ to $L$ ) micrographs of mussel tissues in control (A, $E, I)$, exposed to 3.9 $\pm 0.6 \mu \mathrm{g} \cdot \mathrm{L}^{-1} \mathrm{CBZ}(\mathrm{B}, \mathrm{F}, \mathrm{J}, \mathrm{K}), 280 \pm 20 \mathrm{ng} \cdot \mathrm{L}^{-1} \mathrm{MeHg}(\mathrm{C}, \mathrm{G}, \mathrm{L})$ and the co-exposure $(\mathrm{D}, \mathrm{H})$. Gill filaments $(A$ to $D$, bar $=20 \mu \mathrm{m})$ showing erosion of the ciliated border (e), cell vacuolization $(v)$, necrosis $(n)$, lysis $(I)$, or filament with abnormal shape $\left({ }^{*}\right)$. Fibrosis was revealed in blue by indigo in most filament gills $(x)$ of exposed mussels. Digestive glands ( $E$ to $H$, bar=100 $\mu \mathrm{m}$ ), showing fibrosis $($ (x), hemocoel cell infiltration (I), atresia degenerative tubules (DT) and altered tubules with necrotic digestive cells (arrow). Digestive cells (I to $\mathrm{L}$, bar=2.5 $\mu \mathrm{m}$ ) showing hyperactive cells with high amount of RER and mitochondria (Mi), mostly normally conformed, and altered cells with enlargement of the nuclear inter-membrane space (eim), rare and collapsed cisternae of RER (cRER), dilated cisternae of rough endoplasmic reticulum (dRER) and altered mitochondria (aMi) which broken cristae, loss of external membrane integrity and frequent mitochondrial bodies.

883

884 Figure 4: Relative gene expression levels of $g s t$ (A), cat (B), sod (C) and $m t$ (D), activities of GST (E), 885 CAT (F), SOD $(\mathbf{G})$ and LOOH concentration $(\mathbf{H})$ in gills and digestive glands of $D$. polymorpha at D1 and $\mathrm{D7}$, exposed to control (filled, blank) $3.9 \pm 0.6 \mu \mathrm{g} \cdot \mathrm{L}^{-1} \mathrm{CBZ}$ (green stripes), $280 \pm 20 \mathrm{ng} \cdot \mathrm{L}^{-1} \mathrm{MeHg}$ (blue checkerboard) and the co-exposure (filled, yellow) (mean \pm SEM, $n=6$ to 8 animals; ${ }^{*} p<0.05$ vs control). 

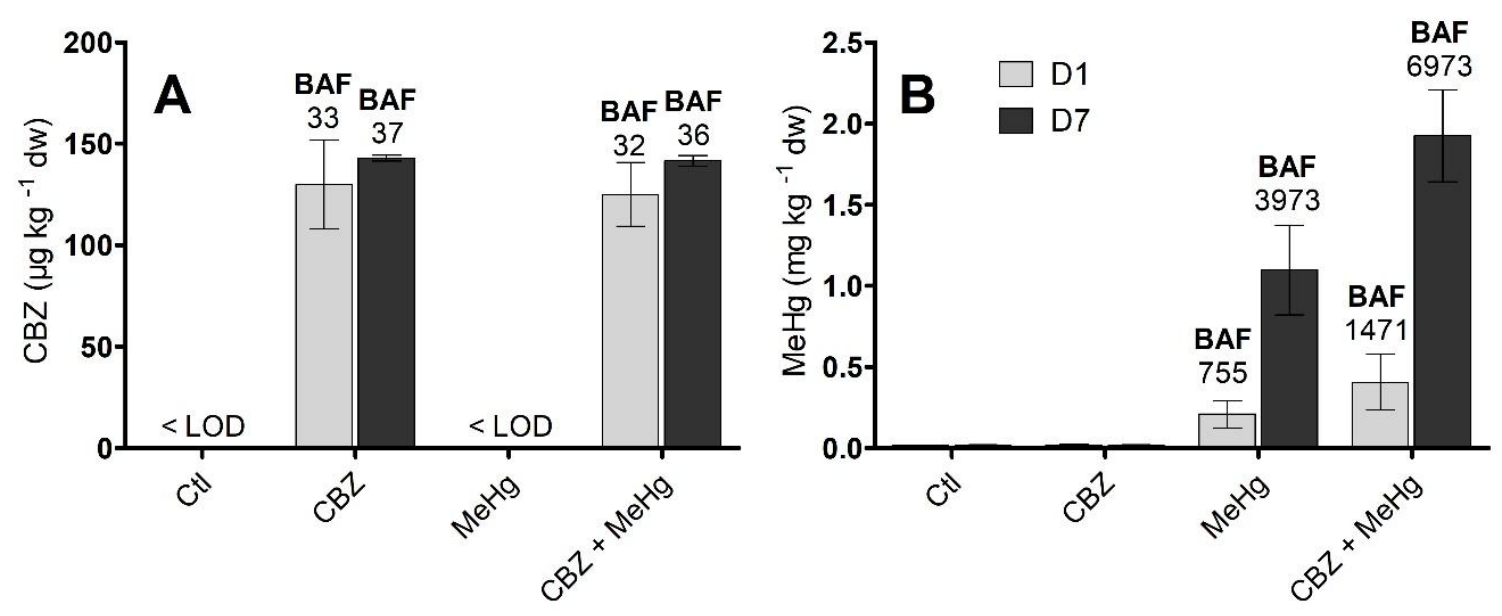

890

Figure 1 
$\begin{array}{lll}-2.3 & 1: 1 \quad 2.3\end{array}$

$\log _{2} \mathrm{FC}$

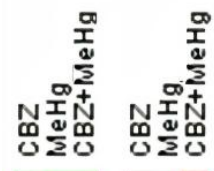

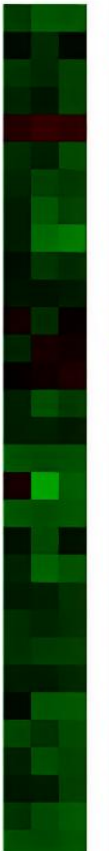

Alanine

a-aminobutyric Acid

Ascorbic acid

Aspartic acid

Citrulline

Cytosine

Erythritol

Fumaric acid

g-aminobutyric acid

Glucose

Glutamic acid

Glyceric acid

Glycerol

Glycerol 3P

Glycine

Inositol

Isoleucine

Lactic acid

Leucine

Lysine

Malic acid

Mannose

Methionine

Phenylalanine

Phosphoric acid

Pipecolic acid

Proline

Putrescine

Serine

Threonine

D1 D7

Valine

Figure 2 

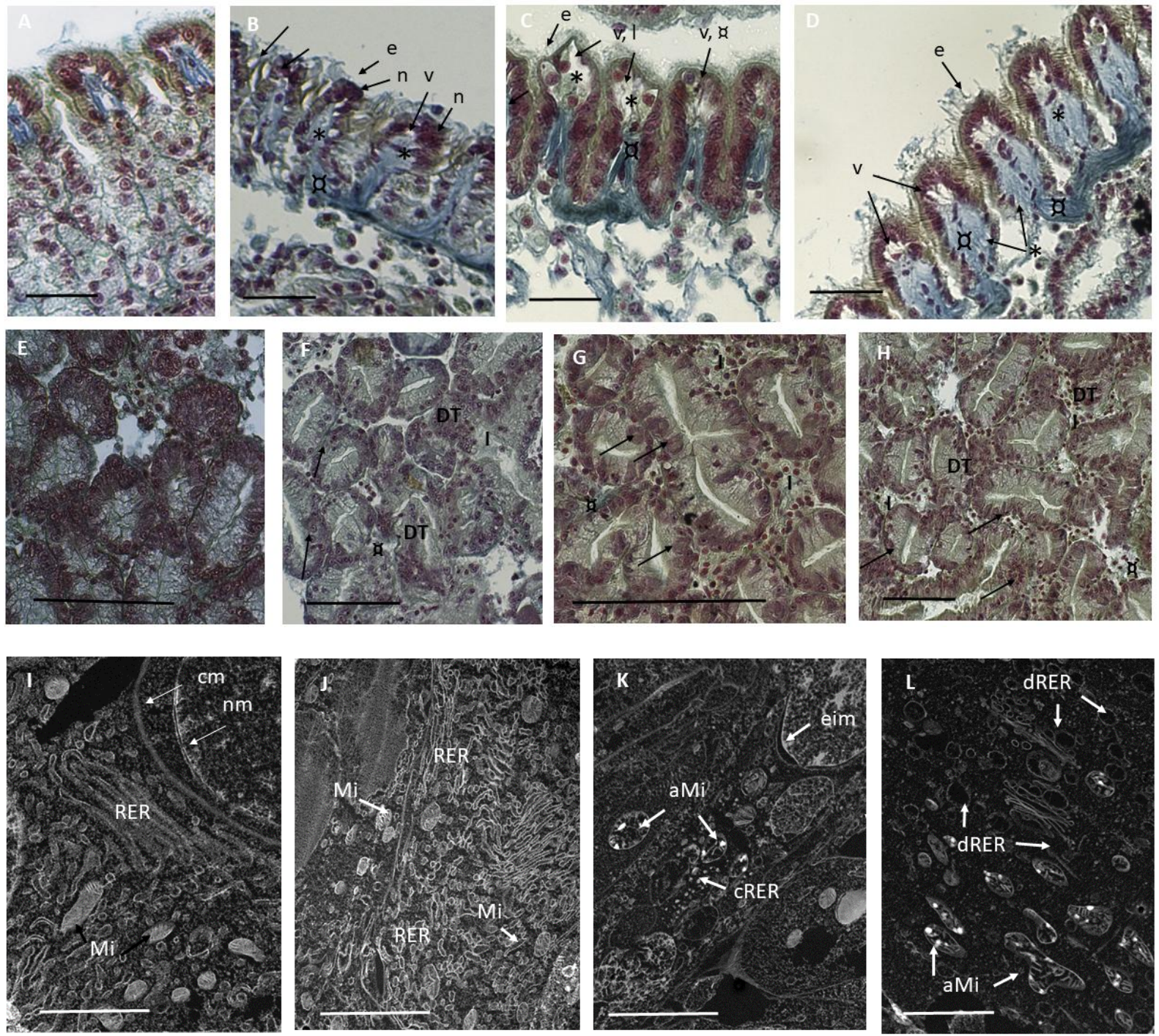

Figure 3

897 

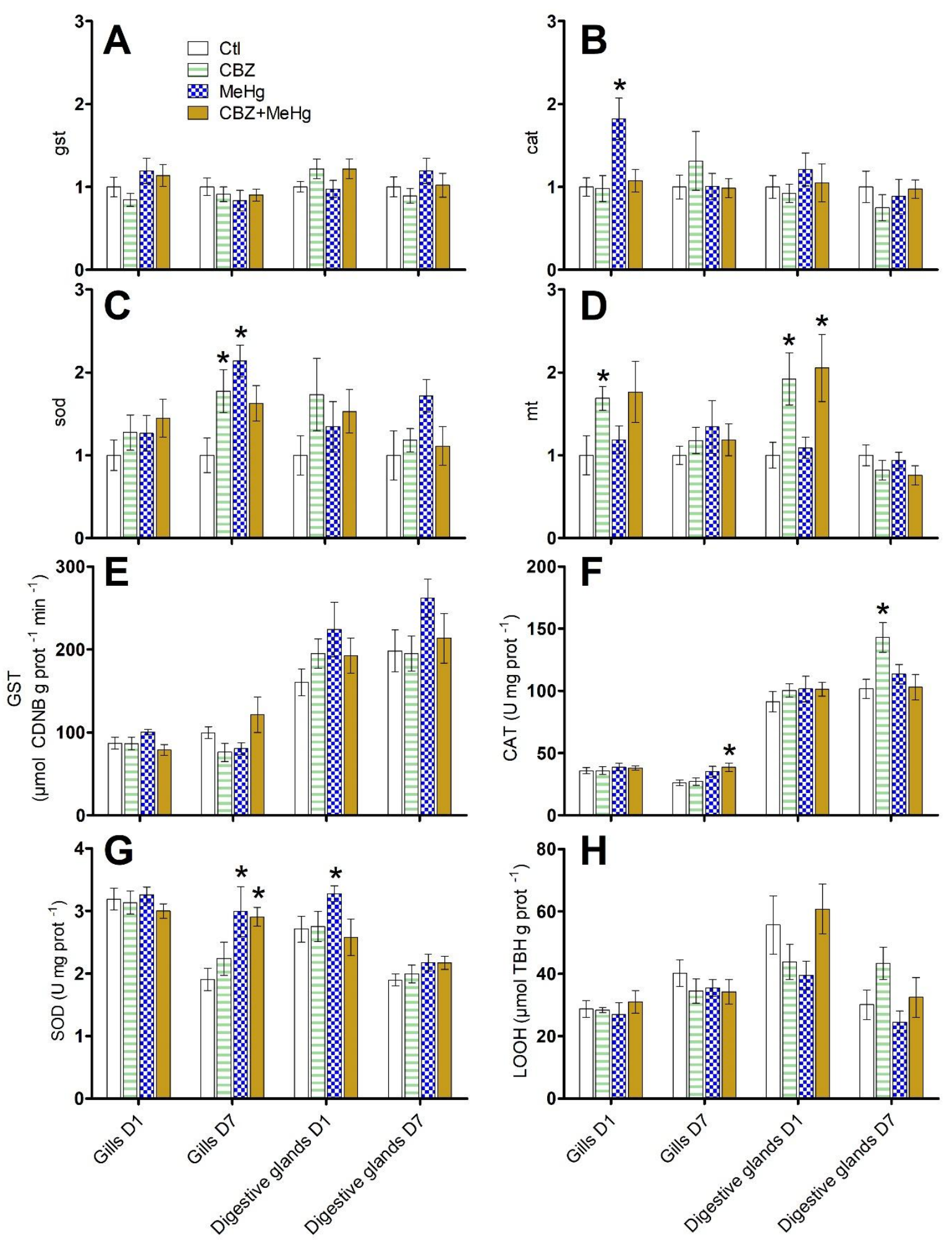

898

$899 \quad$ Figure 4 